Technostress: Negative Effect on Performance and Possible Mitigations

Short running title: Effect of Technostress on Performance 


\title{
Technostress: Negative Effect on Performance and Possible Mitigations
}

\begin{abstract}
We investigate the effect of conditions that create technostress, on technology-enabled innovation, technology-enabled performance, and overall performance. We further look at the role of technology self-efficacy, organizational mechanisms that inhibit technostress, and technology competence as possible mitigations to the effects of technostress creators. Our findings show a negative association between technostress creators and performance. We find that, while traditional effort-based mechanisms like building technology competence reduce the impact of technostress creators on technology-enabled innovation and performance, more empowering mechanisms like developing technology self-efficacy and IS literacy enhancement, and involvement in IS initiatives are required to counter the decrease in overall performance due to technostress creators. Noting that the professional sales context offers increasingly high expectations for technology-enabled performance in an inherently interpersonal and relationship oriented environment with regard to overall performance, and high failure rates for IS acceptance/use, the study uses survey data collected from 237 institutional sales professionals.
\end{abstract}

Keywords: Technostress, Technology-enabled performance, Technology self-efficacy, Technology-enabled innovation, Sales force automation, Sales force performance. 


\section{Technostress: Negative Effect on Performance and Possible Mitigations}

\section{INTRODUCTION}

Technostress is stress that users experience as a result of their use of Information Systems (IS) in the organizational context (e.g. Brod, 1982; Weil and Rosen, 1997; Tarafdar et al., 2007; Ayyagari et al., 2011). With rapid proliferation of IS use across functional areas, it is emerging as an important area for scholarly research in various contexts. Research has identified technostress creators, that is, reasons why individuals experience technostress, and showed that technostress manifests its effects in the form of increased role overload, role conflict, exhaustion and burnout and decreased job satisfaction, (e.g. Tarafdar et al., 2007; Ragu-Nathan et al., 2008; Ayyagari et al., 2011), providing a broad and general theoretical foundation for examining technostress. There are also more focus-driven studies such as technostress from use of electronic and online cataloguing and reference database systems in libraries (e.g. Enis, 2005), and ICT in Chinese organizations (e.g. Tu et al., 2005; 2008).

Stress has been regarded as a context-specific phenomenon that reveals important insights when examined for specific types of outcomes and mitigating mechanisms relevant to the particular setting of the study (Cooper et al., 2001). The importance of context specific studies rests on the need for understanding how general concepts apply to dissimilar contexts (Johns, 2006). There have therefore been calls for continued theoretical and scholarly development in the technostress domain by investigating the technostress phenomenon in particular contexts entailing specific types of technologies, roles or tasks (e.g. Ayyagari et al,. 2011; Shu et al., 2011). In this paper, we examine technostress in the context of the role of the professional salesperson.

The past few years have seen a powerful and pervasive trend of task computerization in roles that are inherently highly human-interfacing. The professional sales function, which has seen substantive investments in sales force automation and customer relationship management applications (Ahearne and Rapp, 2010; Erffmeyer and Johnson 2001) provides an appropriate illustration. Use of these applications requires sales professionals to effectively accomplish critical tasks using IS. However, given that salespeople would rather spend time in front of customers than behind a computer 
screen (e.g. Rangarajan et al., 2005; Geiger and Turley, 2006; Holt, 1998), there is an inherent contradiction between a natural orientation towards building relationships with customers (e.g. Crosby et al., 1990; Morgan and Hunt, 1994), and expected use of IS that might reduce the time spent in personal interaction with them. The professional sales context thus represents a rich domain for examining technostress, because critical sales tasks and sales innovation often rely on IS (Barker et al., 2009), sales professionals are particularly subject to stress in general (Singh, 1998), and IS initiatives are often rejected by sales professionals (Homburg et al., 2009; Speier and Venkatesh, 2002) despite substantial investments in sales technology (Ahearne and Rapp, 2010; Erffmeyer and Johnson, 2001). Further, this context can illustrate how technostress might manifest across a variety of service industries and customer-interfacing careers.

While conditions that create technostress, that is, technostress creators, are negatively associated with productivity and user satisfaction with IS (e.g. Tarafdar et al., 2007; 2010), their relationship with specific performance outcomes has not been examined. Parallelly, given the strategic importance of the salesperson's role (Hunter and Perrault, 2007; Storbacka et al., 2011), sales force IS are intended to enhance his or her performance and facilitate innovation (Ingram et al., 2002). Specifically then, the objective of this paper is to examine the impact of technostress creators on the sales professional's innovation and performance. Noting that organizational mechanisms can alleviate the effects of technostress (Ragu-Nathan et al., 2008), and that IS mediated tasks are particularly stressful for "those reps that lack the [technical] wherewithal (Rich, 2002)", we examine respectively, the role of organizational technostress inhibitors, and the sales professional's technology self-efficacy and technology competence in countering the impacts of technostress creators. We integrate logics from the literatures on technostress, social cognitive theory and IS adoption in marketing/sales roles, to theoretically develop hypotheses explaining relationships among technostress creators, technostress inhibitors, technology self-efficacy, technology competence, technologyenabled innovation, technology-enabled performance and sales performance. We empirically test the hypotheses through structural equation models on survey data from 237 business-to-business sales professionals.

The paper theoretically advances the emerging technostress discourse by demonstrating that stress creating conditions from use of IS can manifest in adverse 
effects on outcomes that are technology enabled as well as broader outcomes of the overall performance in the role. Traditional effort-based mechanisms such as technology competence, can address the negative impacts on technology-enabled outcomes. Enabling or empowerment oriented routes represented by technology self-efficacy and technostress inhibitors are required to counter negative impacts on overall performance. As a related contribution, the paper highlights the importance of technostress in the sales literature by suggesting that conditions that create technostress represent $a$ possible reason for low technology-enabled innovation and performance of sales professionals.

We next present theoretical background on technostress, IS use by sales professionals and social cognitive theory. Hypotheses are developed next, followed by methods, analysis and results. We conclude with discussion of contributions and limitations.

\section{THEORY BACKGROUND}

\subsection{Technostress}

The phenomenon of "Technostress", first introduced in trade literature (Brod, 1982; Weil and Rosen, 1997), describes the situation of stress experienced by the individual due to an inability to adapt to the introduction of new technology in a healthy manner. In the organizational context, technostress describes the stress phenomenon due to use of IS for organizational tasks and can be attributed to characteristics of modern IS such as constant presence, and constant change (Ayyagari et al., 2011). Initial studies from psychology (Arnetz and Wiholm, 1997) noted physical impacts such as fatigue, headache, restlessness, and irritability from stress associated with increased workload due to IS-enabled process reengineering, and increased sensitivity to electric and magnetic fields from prolonged work with computer-based visual display units.

The "Transaction Theory" of stress (Lazarus 1966) from organizational psychology has formed the basis for theoretical conceptualization of the phenomenon of technostress in the IS literature. It describes the phenomenon of stress as a combination of a demand condition that causes the stress (stress creators or "stressors") and the individual's response to it (manifest adverse outcomes referred to as "strain"). What is referred to as "stress" is therefore a phenomenon or transaction that encapsulates relationships between these concepts, rather than a single construct (McGrath 1976, Cooper et al 
2001, page 12). Research on workplace stress has focused on different aspects that comprise the stress phenomenon. These include stress creators such as role overload and role conflict (Kahn et al. 1981, Rizzo et al.1970, Ivancevich and Matteson 1980) and strains such as disruptive behavior dissatisfaction at work, lack of job involvement, and poor job performance (Kahn et al. 1981, Jackson and Schuler 1985, Kahn and Bysosiere 1992). Organizational mechanisms to address stress situations for employees are embodied in situational factors that can reduce the impact of stressors. They include, for instance, job control and social support (Karasek 1979).

In a similar way key aspects of the technostress phenomenon (see Table 1) are "technostress creators" (conditions that create stress due to ICT use), "strain" (manifest conditions), and "technostress inhibitors" (mitigating conditions) (Ragu-Nathan et al., 2008). "Technostress creators" include techno-overload, techno-complexity, technoinsecurity, techno-uncertainty and techno-invasion. They describe respectively, the stress creating aspects of application multitasking and information overload technical problems, continual relearning and consequent job-related insecurities, frequent system upgrades and consequent uncertainty, and constant connectivity, associated with organizational use of IS by individuals. Technostress manifests in various conditions such as higher levels of role stressors (Tarafdar et al., 2007), and decreased job satisfaction, organizational commitment (Ragu-Nathan et al., 2008), productivity (Tarafdar et al., 2007) and end user satisfaction with IS (Tarafdar et al., 2010). Work home conflict, role ambiguity, job insecurity and overload due to characteristics of modern IS are associated with feelings of exhaustion and burnout (Ayyagari et al., 2011). Organizational interventions that can reduce strain impacts are called "technostress inhibitors".

\begin{tabular}{|l|l|l|l|}
\hline \multicolumn{2}{|l|}{ Table 1: Key Concepts and Definitions } \\
\hline Concept & Creators of Technostress & Strain & $\begin{array}{l}\text { Inhibitors of } \\
\text { Technostress }\end{array}$ \\
\hline & Stressor: & Outcome: & \\
$\begin{array}{l}\text { Conceptual } \\
\text { Origin } \\
\text { by temand' individual (1) to be greater } \\
\text { than his or her ability to handle it; } \\
\text { and (2) as having adverse } \\
\text { consequences if not handled } \\
\text { (Lazarus 1966, McGrath 1976, } \\
\text { Rizzo et al.1970, Ivancevich and } \\
\text { Matteson 1980) }\end{array}$ & $\begin{array}{l}\text { An adverse condition } \\
\text { manifest by the individual } \\
\text { as a response to the } \\
\text { process of stress } \\
\text { (Lazarus 1966, Cooper et } \\
\text { al 2001, Kahn et al 1979, } \\
\text { Kahn et al. 1981, } \\
\text { Jackson and Schuler } \\
\text { 1985, Kahn and } \\
\text { Bysosiere 1992) }\end{array}$ & $\begin{array}{l}\text { Situational Condition: } \\
\text { Organizational } \\
\text { mechanisms to address } \\
\text { stress situations for } \\
\text { employees (Karasek } \\
1979, \text { House 1981) }\end{array}$ \\
\hline
\end{tabular}




\begin{tabular}{|c|c|c|c|}
\hline Definition & $\begin{array}{l}\text { Conditions or factors that can } \\
\text { create stress due to ICT use: } \\
\text { Techno-overload, techno- } \\
\text { complexity, techo-invasion, } \\
\text { techno-insecurity, techno- } \\
\text { uncertainty; technology } \\
\text { characteristics such as } \\
\text { usefulness, complexity, reliability, } \\
\text { pace of change, presentee-ism, } \\
\text { anonymity }\end{array}$ & $\begin{array}{l}\text { Manifest outcomes of } \\
\text { stress due to ICT use: } \\
\text { Reduced job satisfaction, } \\
\text { productivity, innovation, } \\
\text { commitment to the } \\
\text { organization. } \\
\text { Increased role overload, } \\
\text { role conflict, perceptions } \\
\text { of being drained and } \\
\text { burned out from use of } \\
\text { ICT }\end{array}$ & $\begin{array}{l}\text { Organizational support } \\
\text { mechanisms that can } \\
\text { mitigate the effects of } \\
\text { stress due to ICT use: } \\
\text { Facilitate technical } \\
\text { literacy, provide technical } \\
\text { support, facilitate } \\
\text { technology involvement }\end{array}$ \\
\hline Literature & $\begin{array}{l}\text { Tarafdar et al 2007, Ragu-Nathan } \\
\text { et al } 2008 \text {, Ayyagari et al } 2011\end{array}$ & $\begin{array}{l}\text { Tarafdar et al } 2007 \\
\text { Ragu-Nathan et al } 2008, \\
\text { Ayyagari et al } 2011 \\
\text { Tarafdar et al } 2011\end{array}$ & Ragu-Nathan et al 2008 \\
\hline
\end{tabular}

A few studies have examined technostress more specifically. One group focused on stress among librarians, due to rapid introduction of successive computer-based library cataloging, retrieval and database systems such as Lexis-Nexis (Van Fleet and Wallace, 2001). It showed that pace of change of library and reference information systems were key causes of technostress (Ennis, 2005; Bartlett, 1995). The strains were computer use related anxiety, feelings of isolation and frustration, indifference to needs of library users and negative attitudes towards computer-based information sources (Kupersmith, 1992), from which self-paced training, communication and bolstered staffing helped to provide relief (Ennis, 2005; Bartlett, 1995). A second group reporting results from IS use in Chinese organizations, found that levels of technostress creators are positively related to power centralization and an organization culture that encourages innovation (Wang et al., 2008), but with no reduction in productivity (Tu et al., 2005). It also showed that higher dependence on IS for completion of routine work tasks and lower levels of computer self-efficacy are associated with higher levels of technostress creators (Shu et al., 2011).

In the literature, stress manifests in and is assessed through relevant workplace responses such as lack of job satisfaction, absenteeism, burnout and exhaustion (Kahn and Byoseire, 1992; Jackson and Schuler, 1985; Jex and Beehr, 1991). In particular, reduced job performance is a key manifestation, of significance to the organization and hence an important variable of study (Cooper et al., 2001). Studies examining the impact of stressors on performance for different levels of task difficulty (McGrath, 1976) find low levels of experienced stress manifest in better performance at difficult tasks. Stress- 
creating conditions reduce the individual's job performance, and result in increased mistakes and accidents at specific tasks (Kahn and Byosiere, 1992). Trade studies in technostress suggest that it hampers performance in a given job role, and results in computer use related mistakes such as wrong entry of data (Brod, 1982). Technostress creators have been associated with decreasing ability to use IS to improve work (Tarafdar et al., 2010). From this (limited) investigation of performance impacts of technostress, we note that technostress creators can have potentially adverse impacts on the overall performance in the role, as well as on performance relating to the individual's use of IS for accomplishing tasks.

\subsection{Contextualizing Technostress}

Much of existing research in technostress provides a broad and general theoretical foundation for analyzing the phenomenon, primarily articulating different creating conditions and general adverse manifest effects. The use of IS happens in a wideranging instantiations of users and usage situations (Lee and Baskerville 2003). 'Context' refers to specifics of a given situation in which IS are developed or used (Orlikowski and lacono 2001). 'Contextualization' involves linking the variables and relationships studied, to these specifics. Context-specific theoretical development thus focusses on the interplay between IS, users, and usage situations (Lee and Baskerville 2003) and helps to identify how context modifies understanding of a given IS related phenomenon (Tsui 2007). Generalized understanding of a phenomenon can thus yield richer theoretical insight and more practically actionable suggestions if further developed by taking context taken into consideration.

Stress is a context-specific phenomenon; different stress creating conditions, strains and situational variables are revealed or highlighted depending on the stress creating situation under study. For instance when examined in organizational/work contexts, stress creating conditions include stress due to role and work task (Kahn et al 1981), strain includes dissatisfaction at work, lack of job involvement and poor job performance (Kahn et al, 1981; Jackson and Sculer, 1985; Jex and Beehr, 1991), and situational factors include social support and job control (Karasek 1979).

Similarly, studies suggest that continued theoretical advances in our understanding of technostress should build on that to reveal insights in particular contexts, such as from 
use of specific technologies/applications (e.g. mobile devices and 24/7email applications), or from the perspective of specific types of affected outcomes such as task performance or task attention (e.g. Ayyagari et al., 2011; Shu et al., 2011). In sum therefore, context-specific theory development in technostress would focus on the interplay between the characteristics of technologies, users, and usage contexts. Such contextualization presents an important theoretical development opportunity for understanding this increasingly recognized phenomenon, is lacking in the current technostress literature, and provides the theoretical backdrop for the focus of this paper.

\subsection{Use of IS by Sales Professionals}

In the context of the sales literature, "IS" or "technology" is defined as: "any type of information technology [or computer application] that can help enable or facilitate the performance of sales tasks (Ahearne and Rapp, 2010)." We describe four key observations that pertain to the use of IS by sales professionals, which make this context an interesting one for studying adverse impacts on performance outcomes from technostress and potential ways to counter them.

First, initial research examined sales technology implementation/adoption (Ahearne et al., 2004; Jones et al., 2002). They found that introduction of such applications could increase sales employee stress and turnover (Speier and Venkatesh, 2002), and IS related technophobia (Rich, 2002) during the implementation process. More recently, however, greater attention has been placed on ongoing use and assimilation of IS (Ahearne et al., 2008; Ahearne and Rapp, 2010; Ahearne et al., 2004; Rangarajan et al., 2005; Rapp et al., 2008). While use of IS by the sales professional can result in positive effects on administrative performance and customer service (Ahearne and Rapp, 2010), it is also associated with negative behavioral impacts such as increased absenteeism and voluntary turnover, and decreased organizational commitment and job satisfaction (Ahearne and Rapp, 2010).

Second, the role of the sales professional, given its relationship orientation, is particularly vulnerable to reluctance to use technology (Buehrer et al., 2005). There is strong positive association between time spent with customers and probability of making quota, indicating a conflict between building relationships with customers, and expected use of IS that might prevent face-to-face interaction with them (Jones et al., 2002). Such 
a situation could create potential for sales professionals to experience technostress and possibly affect immediate task performance as well as overall performance in the sales role.

Third, there is an expectation from the professional sales person to use IS in support of key aspects of his or her role, such as communications and customer relationships (Rodriguez and Honeycutt, 2011). This requires them to utilize IS to co-create innovative solutions with customers (Storbacka et al., 2011) and adapt to the specific customer situation by using IS. Each of these requires innovation and creativity in using IS (Wang and Netemeyer, 2004) in order for it to be successfully executed.

Fourth, professional salespeople are particularly subject to work stress in general (Goolsby, 1992; Singh, 1998) due to the boundary roles they play, multiple internal and external groups they service, and the dynamic environments in which they operate. Given these other stressors already present in the environment, stress due to IS use may be particularly important as an additional stress and a potentially crucial bottleneck to appropriating benefits from use of IS.

\subsection{Social Cognitive Theory}

Bandura's work on Social Cognitive Theory (Bandura, 1982) suggests that an individual's beliefs about how well they can perform a certain task shape their attitudes to that task. In particular, self-efficacy, the belief that one has the ability to perform a particular behavior or task, shapes the individual's responses to demands associated with performing that task. For instance, high technology self-efficacy could lead to the choice to use the technology, and greater effort and persistence when any challenges are faced with its use (Bandura 1991). Technology self-efficacy or computer selfefficacy, particularizing this idea to the context of IS use, represents an individual's judgment about his or her ability to use computers in the accomplishment of a task (Compeau and Higgins, 1995). Higher self-efficacy is associated with greater computer usage (Compeau and Higgins, 1995), lower computer related anxiety (Compeau and Higgins, 1995), higher comfort in using computers (Compeau et al., 1999) and a generally positive attitude towards them (Venkatesh and Davis, 1996). However, we do not know how technology self-efficacy impacts work performance in the context of technostress. 
Self-efficacy is particularly important in the sales area and viewed as crucial to success, as salespeople face challenges that are rarely present in other careers areas to the same degree, such as frequent rejection and intense competition (Jones et al. 2007). Salespeople who hold self-efficacious beliefs can adapt to challenges more readily and are more persistent in their pursuit of customer satisfaction and making sales (Krishnan et al. 2002). The impact of a strong positive belief system is likely to transfer to beliefs about tasks associated with the job, including technology use. Given this, it is important to have a theoretical basis to incorporate the salesperson's self-efficacious beliefs and their impact on performance vis-à-vis technostress.

The sales literature suggests that various self-efficacies of the salesperson are important to different aspects of performance (Brown et al., 2007). For instance, task related selfefficacy positively impacts the salesperson's command over his or her ability to perform well at sales tasks (Kumar and Uzkurt, 2010). In the context of the salesperson's use of IS, technology self-efficacy leads to increased usage of newly implemented sales IS (Mathieu et al., 2007). Sales professionals with higher technology self-efficacy feel that they have greater control and capability in using sales force IS (Mathieu et al., 2007). It is not difficult to imagine then, that they would feel more enthusiastic, and less threatened or incapable, about using IS. Thus, although technology self-efficacy has not been specifically studied in the context of on-going use of existing IS by sales professionals, those with higher technology self-efficacy are less likely to attribute negative impressions to IS.

It is in the backdrop of these observations, namely, research opportunity for contextualization in technostress literature, scant research in specific performance effects of technostress creators, and increasing computerization of the professional sales function that has implications for poor performance, that we undertake to examine how conditions that create technostress impact the performance of the sales person.

\section{HYPOTHESES}

We propose the research model as shown in Figure 1. We first develop the set of hypotheses ( $\mathrm{H} 1$ through $\mathrm{H} 3$ ) linking technostress creators to sales performance and technology enabled innovation, and technology enabled innovation to technologyenabled performance. We next develop the second set of hypotheses ( $\mathrm{H} 4$ through $\mathrm{H} 7$ ) 
where we examine the role of technology self-efficacy as a possible moderator of the relationship between technostress creators and sales performance, of technostress inhibitors as a possible reducer of technostress creators, and of technology competence as a potential booster of technology enabled innovation and technology enabled performance. The inclusion of variables and relationships is grounded in the specifics of the technostress phenomenon in the context of the sales professional's use of IS, as explained when relevant, in particular parts of the following sub-sections.

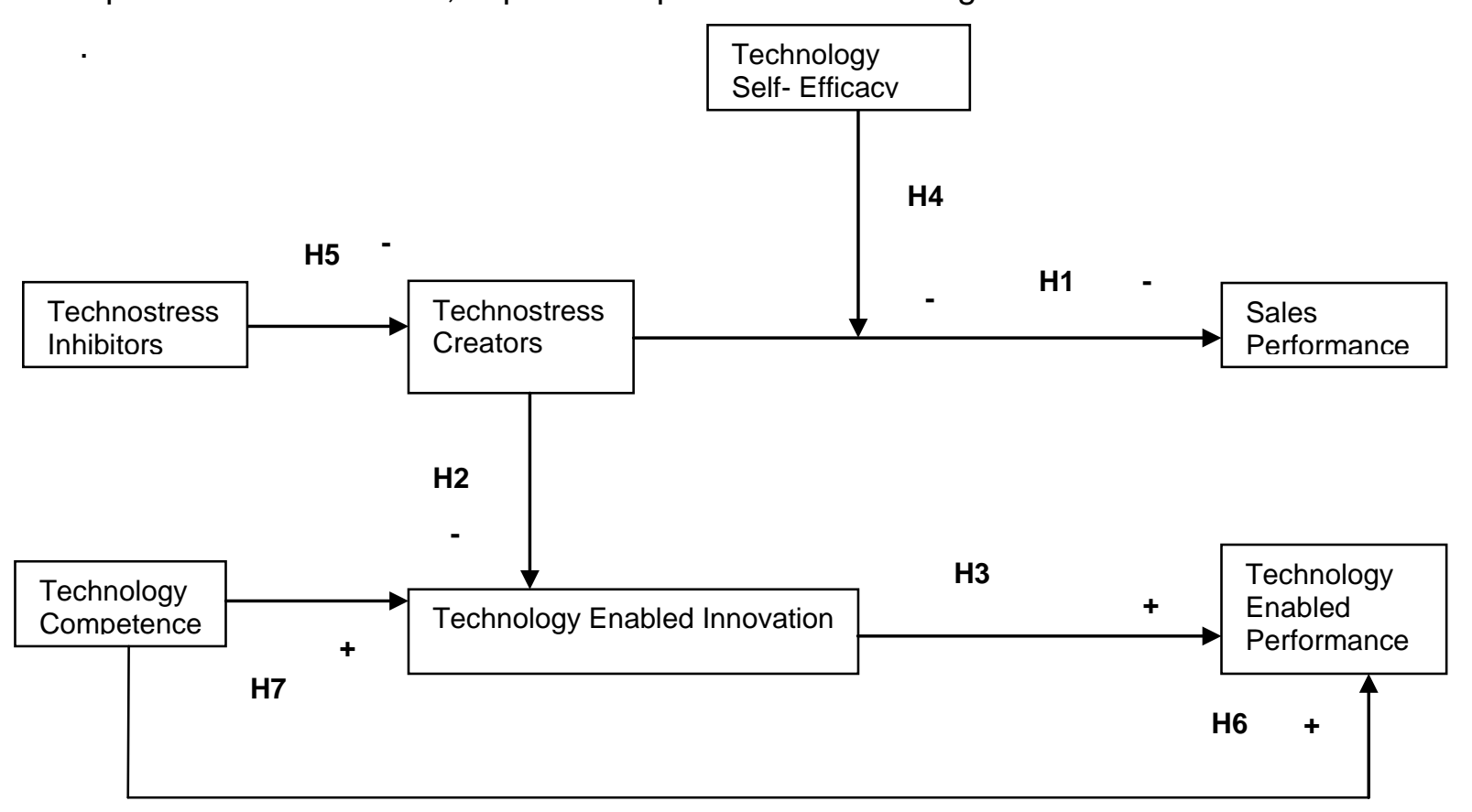

Figure 1: Research Model

\subsection{Relationships between Technostress Creators and Sales Performance,} Technostress Creators and Technology Enabled Innovation, and between Technology Enabled Innovation and Technology Enabled Performance

Sales performance indicates an overall outcome of the sales role and is often measured as performance against sales quota (Ahearne et al., 2004; Chonko et al., 2000; Sojka and Deeter-Schmelz, 2008). Because the key role of the salesperson is to generate revenue for the firm, this is an important and most typical outcome measure. As such, for a salesperson to successfully get the sale, a number of activities must come to successful completion, such as, but not limited to successful identification of potential customers, diagnosis and problem-solving of the customers' needs, relationship building activities, and follow up. A deficiency in any step could result in failure to successfully 
close the business (Plouffe et al., 2013). We know that stress due to changes in technology such as introduction of a new CRM system for capturing customer data can manifest in decrease in individual productivity under certain conditions (Ahearne et al., 2008; Jelinek 2013; Nelson and Kletke, 1990; Sainfort, 1990). Specifically in the case of technostress creators, techno-overload implies greater work required in using IS. For instance, a CRM system may require information about the customer that was previously tacitly held in the salesperson's memory, to be electronically captured and recorded. Techno-complexity entails effort and time in understanding how to use IS. Both may leave little time for other tasks that are necessary for achieving sales performance. Techno-insecurity might necessitate forced and isolated effort in learning how to use IS, potentially leading to inadequately informed and non-beneficial application of IS to important tasks necessary for achieving quota. Techno-invasion leads to increased demands for working at sales tasks from home, in potential conflict with family activities and priorities. Salespeople may use IS such as CRM applications on smartphones that allow them to be on call with customers at all hours. Individuals feel drained, tired and burned under such a situation (Ayyagari et al., 2011), resulting in work related performance of sub-par quality. Based on these arguments, it is plausible that technostress creators prevent the individual from effectively accomplishing tasks necessarily for achieving sales performance, thereby manifesting in impaired overall sales performance ${ }^{1}$. We therefore propose:

\section{H1: Technostress Creators is negatively related to Sales Performance.}

According to Hunter and Perrault (2007), "uses of technology have differential effects on various aspects of performance...", of the salesperson. Therefore it is important to examine the impact that technostress creators might have on outcomes relating to use of IS for sales tasks (e.g. market intelligence collection using a sales force application). In particular we consider technology-enabled innovation and technology-enabled performance, since the professional salesperson utilizes IS largely for developing creative solutions for customers and his/her own efficiencies.

The salesperson's success is measured not just in terms of business closed and quota

\footnotetext{
${ }^{1}$ We do not include 'techno-uncertainty'. Salespeople are frequently remote and not as subject to headquarter or facility application and hardware upgrades as other types of workforces; studies on contextspecific theorization (e.g. Whetten 2009) suggest that where appropriate, context-sensitive versions of variables may be required to make their meaning functionally applicable.
} 
achieved, but also in terms of innovative customer service and long-term customer relationships (c.f. Zallocco et al., 2009). A key aspect of the salesperson providing value comes from innovations in products/solutions sold and in customer interfacing processes (Walter et al., 2001). Innovating by creatively utilizing sales technologies is therefore an expected outcome of their use (Hunter and Perrault, 2007). Based on Sun (2006), we define technology-enabled innovation as the development and implementation of creative ideas and solutions for the customer through application of sales force IS.

Stressors place demands on the person experiencing stress and induce an externally controlling situation (Karasek, 1979). According to Cognitive Evaluation Theory (Deci, 1972; Deci and Ryan, 1985), situations perceived as externally controlling result in an extrinsic orientation, which impairs innovation (Ryan et al., 1983), and specific to the sales context, impair the salesperson's ability to innovate (Pullins, 2001). Specifically, the dimensions of technostress creators reduce the effectiveness with which they can use applications to enhance their innovation at work. For example, because of technooverload they multi-task with several applications and information processing tasks. Multi-tasking results in hurried and ineffective information processing, leaving insufficient time and attention for accomplishing tasks in imaginative ways, and for exploring creative work processes (Amabile et al., 1996). For salespeople this means they become more routinized and scripted rather than collaborative and value enhancing. In these conditions, they find it difficult co-create and develop unique solutions with individual customers (Pullins, 2001). Techno-invasion, stemming from IS that include pervasive networks and mobile computing devices, enables "anytime anyplace" access for salespeople through constant and ubiquitous connectivity. It impairs innovation because of unnecessary interruptions to work that prevent sustained concentration that is required for innovation. Techno-complexity places requirements on salespeople to develop frequent new skills required for using IS; something they are often unwilling or unable to do. As they try to unsuccessfully apply their existing solutions to the new technologies, the extent to which they can perform their technology mediated tasks innovatively, decreases. Salespeople who perceive job-related insecurity and anxiety because of techno-insecurity may experience anxiety and low self-confidence when using IS, and hence find themselves unable to be innovative at tasks that involve use of IS. Based on the above arguments, we frame hypothesis 2 :

\section{H2: Technostress Creators is negatively related to Technology Enabled}




\section{Innovation.}

Technology enables performance on various tasks such as satisfying customer needs and communicating with customers. We define technology-enabled performance as the accomplishment of customer-interfacing tasks through use or application of sales force technologies. These types of tasks, particularly in the institutional/business to business context, entail adapting and customizing solutions (Moncrief, 1986) and require an orientation towards innovation and relationship building (Pullins, 2001). Thus technologyenabled performance is contingent on the ability to innovate. Limited evidence shows generally that salesperson innovation improves performance (DiLiello and Houghton, 2008), but it has not been investigated in a technology-enabled environment Thus, we propose the following hypothesis:

H3: Technology Enabled Innovation is positively related to Technology Enabled Performance

\subsection{Impacts of Computer Self Efficacy, Technostress Inhibitors and}

\section{Technology Competence}

Individuals having high self-efficacy are likely to feel in greater control and less troubled by stressors that relate to the area of their self-efficacy. Their response to stressors is thus likely to be less extreme (Spector, 1988), suggesting self-efficacy to be a moderator of the relationship between stressor and manifest stress outcome. From the stress literature we know that individuals with high self-efficacy and higher faith in their ability at their job, show a lower strength of negative relationship between role stressors and job performance (Pierce et al., 1993) and are better able to cope with greater job demands (Schaubroeck and Merritt, 1997; Fox et al., 1995). In general, self-efficacy can be an effective moderating mechanism, since the stressor condition (i.e. relating to use of IS) is relevant to the domain in which the individual feels capable, that is use of IS (Brockner, 1988; Cooper et al., 2001). In the context of IS use by salespersons therefore, we suggest that technology self-efficacy has the potential to be a moderator between technostress creators and sales performance.

Specifically, techno-overload and techno-complexity, embody requirements for more work in understanding how to use IS as well as in actually using IS, potentially taking away time from other tasks necessary for achieving sales performance. Sundaram and 
colleagues (2007) suggest that the ability to appropriate improved sales performance from use of sales IS depends on experience with respect to IS. In particular, sales professionals who feel positive about their ability to use technology are likely to feel in greater control ${ }^{2}$ over their ability to use IS. They are likely to be able to achieve a balance between the extent of extra work they do due to IS and the work they do in tasks that are necessary for achieving sales performance, thus mitigating the negative relationship between technostress creators and sales performance. Higher self-efficacy is associated with higher comfort in using computers (Compeau et al., 1995); salespeople who have high technology self-efficacy are expected to be more enthusiastic, confident and relaxed about using them. Techno-insecurity might necessitate forced and ineffective effort in learning how to deal with constantly changing IS. The confidence associated with high self-efficacy can act as a potential dampener on the extent to which this can reduce sales performance. Techno-invasion leads to increased demands for working at sales tasks such as attending to urgent customer emails from home, creating work-home conflict. Salespeople who are confident and relaxed about using IS are likely to feel less burned out and frustrated in such a situation, thus experiencing a lower adverse effect of techno-invasion on sales performance.

Given these logics, the sales person with high self-efficacy is likely to interpret the presence of technostress creating conditions as less threatening and the stress response would be less intense, suggesting computer self efficacy to be a negative moderator of the relationship between technostress creators and sales performance. We thus frame the following hypothesis.

\section{H4: Technology Self-efficacy negatively moderates the relationship between Technostress Creators and Sales Performance}

Organizations can develop support mechanisms and processes directed towards reducing workplace stressors. These include giving employees more job related information, feedback and training (Beehr, 1998; Jimmieson and Terry, 1998; Cooper et al., 2001). In general, support mechanisms influence the stress process in a number of ways - they can moderate the relationship between the stressor and strain variables

${ }^{2}$ High job control negatively moderates the relationship between high job demands and strain (Karasek, 1979) and may reduce the impact of job stressors (Jones and Fletcher, 1996). 
(Lazarus 1966), or may affect the direct experience of the stressor, by leading individuals to appraise a lower potential intensity of the stressor (Scheck et al., 1997, Cooper et al 2001, pg. 142). For instance, social support has been negatively associated with employees' appraisals of stressors from life events such as death. Frone et al (1995) and Fenlason and Beehr (1994) suggest that when there is a conceptual fit between a type of stressor and support mechanisms, those support mechanisms can directly reduce the intensity of stressors. That is, the specific form of support should be relevant for alleviation of the stressor in question. In the context of technostress, "technostress inhibitors" include three types of organizational mechanisms (RaguNathan et al., 2008) - Literacy facilitation, Technical support provision and Involvement facilitation. They provide support to users through mechanisms that are related to their use of IS (e.g. technical help through help desks, facilitating sharing of technical knowledge, training, facilitating user involvement and experimentation with IS). We thus suggest that they have potential to reduce the individual's experience of the stressor conditions related to their use of IS, in this case, technostress creators.

Literacy facilitation includes mechanisms that encourage and foster sharing of IS related knowledge within the organization. They enable overall understanding and informing of new applications that are implemented in terms of their functionality and how they can be used. They are expected to help sales professionals effectively in corporate IS in their organizational tasks and reduce feelings of having to do "too much" with IS, of "being overwhelmed by IS" even outside work, and of "feeling threatened" by potential employment loss because of inability to come to understand new IS. They thus decrease the overload, invasion and insecurity aspects of technostress creators. Indeed, despite evidence that firms with successful CRM technology applications are more likely to have trained users on the system (Harding et al 2004), we find (e.g. Taylor-West and Saker (2012)) that IS training needs for salespeople are often underestimated. Technical support provision describes mechanisms related to end user support activities and describes the extent to which IS help desk routines are responsive and effective in addressing IS related problems of users, increasing their level of comfort and assurance. These mechanisms allow for salespeople to be trained, guided, and supported in the context of their use of IS, making it easier for them to cope with the demands of learning about new IS and navigating through applications. They alleviate feelings of having to "constantly learn" new IS use, and thus decrease the complexity aspect of technostress 
creators. Anecdotally, Hyle (2009) found that technology support helps insurance salespeople to better serve customers. Involvement facilitation measures the extent to which end users are involved/consulted in IS implementations and IS related changes, encouraged to try out new IS, and rewarded for using them. These mechanisms keep users informed about the rationale for introducing new IS. They enable salespeople to appreciate why specific applications are implemented and what their potential benefits might be. They allow salespeople to understand and accept those changes that IS may bring to their tasks and workflows. These mechanisms thus reduce the insecurity aspect of technostress creators. Evidence from the sales literature (Day and Van den Blute 2002) shows that mechanisms that promote involvement, such as incentives and accountability were important elements in achieving better utilization of CRM by sales professionals. Higher levels of IS involvement in IS design and implementation (Tarafdar et al., 2010) are associated with lower levels of technostress creators. Based on the above arguments we propose the following hypotheses:

\section{H5: Technostress Inhibitors is negatively related to Technostress Creators}

An important contextual variable that characterizes use of IS by the professional salesperson is technology competence (Ritter and Walter, 2004; Walter and Ritter, 2004), defined as his or her ability to use IS productively and with ease in sales tasks. Distinct from technology self-efficacy in that it is focused on the ability to use IS (rather than a belief), it results in a higher quality of IS utilization. It is thus expected to impact performance relating to IS use. The ability to use technology tools with competence or savvy (Onyemah et al., 2010) can potentially result in the sales professional working with IS in a "smarter" manner (Hunter and Perrault, 2007). We also know from the IS literature that users who are familiar with system features and application functionality, can effectively use IS and gain better utilities from IS in terms of performing tasks that are IS mediated (Jasperson et al., 2005). The user's ability to use IS effectively is thus likely to positively influence his or her ability to appropriate benefits from it for their tasks. Based on these arguments, we believe that technology competence is likely to result in improved performance enabled by IS. Therefore we hypothesize:

\section{H6: Technology Competence is positively related to Technology Enabled Performance}

There are emerging ideas that salesperson innovation in the context of technology use 
might be positively impacted by their competence in using that technology (e.g. Kumar and Uzkurt, 2010). Having the ability to gainfully use IS for sales related activities should realize increased effectiveness (e.g. Rapp et al., 2008), including those related to innovative activities required of the new sales role. It is therefore reasonable to expect that technology competence would impact technology enabled innovation; we thus frame the following hypothesis.

\section{H7: Technology Competence is positively related to Technology Enabled Innovation}

\section{METHODS AND RESULTS}

We executed this study through survey research conducted in three steps - (1) Survey design, (2) Data collection, and (3) Data analysis, as described below.

\subsection{Survey Design}

Based on the literature discussed in Section 2, we developed survey items for the model's constructs. Items for "Technostress Creators" and "Technostress Inhibitors" were adapted from Ragu-Nathan et al (2008) and those for "Technology self-efficacy" from Compeau and Higgins (1995). Items for "Technology Enabled Innovation" were drawn from Torkzadeh and Doll (1999) and Sun (2006). The items for these constructs were modified as appropriate for the context of the study. Drawing on traditional measures of overall sales performance (e.g. Ahearne et al., 2004; Chonko et al., 2002; Sojka and Deeter-Schmelz, 2008), a two-item measure of overall sales performance was utilized that asked salespeople to report how well they performed overall and against quota, on a 10-point scale. The items for "Technology Competence" were drawn from studies that propose this construct and address related constructs such as technology savvy with use IS tools (Ritter and Walter, 2004; Walter and Ritter, 2004; Hunter and Perrault, 2007; Onvemah et al., 2010). All of these constructs were defined as being reflective, consistent with literature. "Technology Enabled Performance" was developed for this research to capture the performance aspects that are proposed in the literature to be most affected by sales technology. These include more productive and professionalism interactions with customers (Barker et al., 2009), more time spent with them, and improved customer service and relationship building (Ahearne and Rapp, 2010). Each of these aspects reflects that the salesperson is effectively using IS to enhance task performance, that is, performing well, suggesting this construct to be 
reflective $^{3}$ (Plouffe et al., 2013). Development of this construct included content validation of items by sales managers and sales researchers, as to their appropriateness and relevance. Specifically they were tested for face validity by review from five sales managers of two separate sales organizations and two academic researchers in the sales area.

All items other than Sales Performance were measured on a five point Likert scale: 1 strongly disagree to 5 - strongly agree. A sixth option of "Not Applicable" or "I do not know" was also provided.

\subsection{Data Collection}

To test the hypotheses, the questionnaire survey was provided to sales professionals from three business-to-business organizations (selling business services, building materials, various raw material product categories respectively). Each of these organizations had sales professionals in a territory sales representative role with similar responsibilities. While the products/services sold varied somewhat, the nature of the customers (business professionals and small business owners), selling process (consultative), selling cycle (short to moderate) and nature of the sales decision making (cost-oriented) were very similar. Hence the respondents were largely similar with respect to their sales activities and responsibilities. The applications used were also similar, as was the broad nature of use, and each was typical of the professional sales context. For example, each of the firms had customer relationship management and sales force automation systems that provided standard types of sales technology tools. All the firms had implemented and adopted CRM systems for a reasonably long-enough time such that there were no significant known problems or recent/pending upgrades/changes.

\footnotetext{
${ }^{3}$ Customers will work with a salesperson and purchase from him/her when s/he is performing at a high level (Weitz, 1978). This might be due to several factors such as using the technology to create better solutions, enhance communication and professionalism, and spend more productive time with customers. Each of these items by itself would be an indicator that the salesperson is performing at a high level, thus demonstrating (or reflecting) that he or she is effectively using technology to enhance performance in role. There is no real way to formatively build each component of what goes into a high performance since every customer relationship is unique. Instead we measure through items that would indicate that positive performance is perceived to exist due to the technology use. That is, each of the first order items represents a particular aspect of technology competence and the direction of causality is from the second order construct to its facets, the first order reflectors.
} 
Graduate student researcher assistants from professional sales classes were offered the opportunity to administer the survey for course credit. Students were given training and instructions regarding selection of survey participants (i.e. a business-to-business sales professional) and respondent approval through a signed consent (for identifying their name, title, company, and phone/email contact information). Upon receiving the completed surveys, random checks (phone calls to subjects) were conducted on $10 \%$ of the sample to verify the accuracy of the data collection method. The process netted a total of 237 questionnaires, from 500 initially distributed, giving us a response rate of $47 \%$. In terms of sample demographics, about $66 \%$ of the respondents were male and $34 \%$ were female, more than $70 \%$ had a Bachelor's degree and above, and their ages were evenly spread in 10 year ranges between 26 and 56 years. In terms of professional sales experience, $65 \%$ had an experience of less than 10 years, 23\% between 10 and 20 years and $12 \%$ greater than 30 years.

\subsection{Analysis for Model Testing}

We used measurement and structural equation model (SEM) techniques to estimate construct item loadings and path parameters, as explained in the following steps.

\subsubsection{Psychometric Properties of Constructs}

We first conducted factor analysis in SPSS as an initial test for convergent and discriminant validity of the constructs, as shown in the Appendix Tables 1 through 3 . Items for Technostress Creators loaded onto four factors (TSC_1, TSC_2, TSC_3 and TSC_4), and those for Technostress Inhibitors loaded onto three factors, (TSI_1, TSI_2, and TSI_3), both as theorized. Items for Technology Enabled Performance (TEP), Technology Enabled Innovation (TEI), Technology Competence (TEC) and Technology Self Efficacy (TSE) loaded onto their respective constructs. Table 2 shows the construct items and their reliability (Cronbach Alpha) values. 


\begin{tabular}{|c|c|c|}
\hline Factor (Reliability) & Item & Item Description \\
\hline SP (0.98) & SP_2 & Overall Performance \\
\hline \multirow[t]{5}{*}{ TSE (0.91) } & TSE_1 & I would complete this job using the software package if I had seen someone else using it before trying it myself \\
\hline & TSE_2 & I would complete this job using the software package if I could call someone for help if I got stuck \\
\hline & TSE_4 & $\begin{array}{l}\text { I would complete this job using the software package if I had a lot of time to complete the job for which the software } \\
\text { was provided }\end{array}$ \\
\hline & TSE_5 & I would complete this job using the software package if I had just the built-in help facility for assistance \\
\hline & TSE_6 & $\begin{array}{l}\text { I would complete this job using the software package if I has used similar packages before this one to do the same } \\
\text { job }\end{array}$ \\
\hline \multirow[t]{3}{*}{ TEC (0.92) } & TEC_1 & I can use this technology to improve the quality of my work \\
\hline & TEC_2 & I can use this technology to improve my productivity \\
\hline & TEC_3 & I can use this technology to accomplish more work than would otherwise be possible \\
\hline \multirow[t]{5}{*}{ TSI_1 (0.87) } & TSI_1_1 & Our organization encourages knowledge sharing to help deal with new technology \\
\hline & TSI_1_2 & Our organization emphasizes teamwork in dealing with new-technology related problems \\
\hline & TSI_1_3 & Our organization provides sales force training before the introduction of new technology \\
\hline & TSI_1_4 & Our organization fosters a good relationship between IT department and sales force \\
\hline & TSI_1_5 & Our organization provides clear documentation to the sales force on using new technologies \\
\hline \multirow[t]{4}{*}{ TSI_2 (0.87) } & TSI_2_1 & Our end-user help-desk does a good job of answering questions regarding technology \\
\hline & TSI_2_2 & Our end-user help-desk is well by knowledgeable individuals \\
\hline & TSI_2_3 & Our end-user help-desk is easily accessible \\
\hline & TSI_2_4 & Our end-user help-desk is responsive to end-user requests \\
\hline \multirow[t]{4}{*}{ TSI_3 (0.88) } & TSI_3_1 & Our salespeople are encouraged to try out new technologies \\
\hline & TSI_3_2 & Our salespeople are rewarded for using new technologies \\
\hline & TSI_3_3 & Our salespeople are consulted before introduction of new technology \\
\hline & TSI_3_4 & Our salespeople are involved in technology change and/or implementation \\
\hline \multirow[t]{2}{*}{ TSC_1 (0.90) } & TSC_1_1 & I am forced by this technology* to work much faster \\
\hline & TSC_1_2 & I am forced by this technology to do more work than I can handle \\
\hline
\end{tabular}




\begin{tabular}{|c|c|c|}
\hline & TSC_1_3 & I am forced by this technology to work with very tight time schedules \\
\hline & TSC_1_4 & I am forced to change my work habits to adapt to new technologies \\
\hline & TSC_1_5 & I have higher workload because of increased technology complexity \\
\hline \multirow[t]{4}{*}{ TSC_2 (0.91) } & TSC_2_1 & I spend less time with my family due to technology \\
\hline & TSC_2_2 & I have to be in touch with my work even during my vacation due to this technology \\
\hline & TSC_2_3 & I have to sacrifice my vacation and weekend time to keep current on new technologies \\
\hline & TSC_2_4 & I feel my personal life being invaded due to this technology \\
\hline \multirow[t]{5}{*}{ TSC_3 (0.92) } & TSC_3_1 & I do not know enough about this technology to handle my job satisfactorily \\
\hline & TSC_3_2 & I need a long time to understand and use new technologies \\
\hline & TSC_3_3 & I do not find enough time to study and upgrade my technology skills \\
\hline & TSC_3_4 & I find new recruits to this organization know more about computer technology than I do \\
\hline & TSC_3_5 & I often find it more complex for me to understand and use new technologies \\
\hline \multirow[t]{5}{*}{ TSC_4 (0.90) } & TSC_4_1 & I feel constant threat to my job security due to new technologies \\
\hline & TSC_4_2 & I have to constantly upgrade my skills to avoid being replaced \\
\hline & TSC_4_3 & I am threatened by co-workers with newer technology skills \\
\hline & TSC_4_4 & I do not share my knowledge with co-workers for fear of being replaced \\
\hline & TSC_4_5 & I feel there is less sharing of knowledge among co-workers for fear of being replaced \\
\hline \multirow[t]{3}{*}{ TEI (.90) } & TEl_1 & This technology helps me to identify innovative ways of doing my job \\
\hline & TEl_2 & This technology helps me to come up with new ideas relating to my job \\
\hline & TEl_3 & This technology helps me to try out innovative ideas \\
\hline \multirow[t]{5}{*}{ TEP (0.86) } & TEP_1 & Using technology results in improved customer satisfaction \\
\hline & TEP_2 & Using technology results in more time to meet with customers \\
\hline & TEP_3 & Using technology helps me make my time with customers more productive \\
\hline & TEP_4 & Using technology helps me communicate better with customers \\
\hline & TEP_5 & Using technology helps improve my overall professionalism with customers \\
\hline
\end{tabular}

Note*: "This technology" or "this software" refers to sales force and other sales applications used by the respondent 
We next conducted analysis using component based SEM in PLS as shown in Tables 3 and 4. TSC and TSI are considered as first order constructs with items TSC_1, TSC_2, TSC_3, TSC_4, and TSI_1, TSI_2, TSI_3 respectively, as consistent with literature (e.g. Ragu-Nathan et al., 2008). Each of these was calculated as the mean of their constituent items from Table 2. Table 3 shows the factors loadings for each model construct (there were no cross loadings above 0.4) and Table 4 shows the construct means, construct SD's, inter-construct correlations and square root of AVE values. All the AVE's are greater than the recommended value of 0.5 (Fornell and Larcker, 1981) and all Cronbach alpha coefficients are higher than the recommended value of 0.7 (Nunnally, 1978). The composite reliabilities of the items are also quite high, greater than or close to 0.80 . The square root of the AVE value for each construct is higher than its correlation with all other constructs. These results support good convergent and discriminant validity of the constructs (Wetzels et al., 2009). Table 4 in the Appendix shows the composite reliability, communality and redundancy values of the constructs.

\subsubsection{Common Methods' Bias}

We evaluated the potential presence of common-methods bias, due to data collected from a single respondent using two methods. We used a method factor variable (Lindell and Whitney, 2001; Malhotra et al., 2006) and tested two different models. The first model was an all construct correlated model for all the constructs. In the second model, a method factor variable (a first-order factor in which the measures included the indicators of all the constructs in the research model) was introduced (Podsakoff et al., 2003; Paulraj et al., 2008; Flynn et al., 2010), with the following results. One, the correlations among the constructs of the first-order correlated model did not substantially change with the introduction of the method factor. Two, the significance of the item loadings of the constructs did not change in spite of the inclusion of a method factor. Three, the method factor accounted for $9 \%$ of the total variance and its inclusion only marginally improved the model fit indices. These results indicate low probability of bias, based on which we concluded that common methods' bias would not significantly affect the path model testing for the proposed hypotheses. 
Table 3: Construct Item Loadings (Cross loadings below 0.4 are not shown for clarity)

\begin{tabular}{|c|c|c|c|c|c|c|c|}
\hline & $\begin{array}{l}\text { Sales } \\
\text { Performance } \\
\text { (SP) }\end{array}$ & $\begin{array}{l}\text { Technology } \\
\text { Self Efficacy } \\
\text { (TSE) }\end{array}$ & $\begin{array}{l}\text { Technology } \\
\text { Competence } \\
\text { (TEC) }\end{array}$ & $\begin{array}{l}\text { Technostress } \\
\text { Inhibitors (TSI) }\end{array}$ & $\begin{array}{l}\text { Technostress } \\
\text { Creators (TSC) }\end{array}$ & $\begin{array}{l}\text { Technology } \\
\text { Enabled } \\
\text { Innovation (TEI) }\end{array}$ & $\begin{array}{l}\text { Technology } \\
\text { Enabled } \\
\text { Performance (TEP) }\end{array}$ \\
\hline SP_1 & 0.99 & & & & & & \\
\hline SP_2 & 0.99 & & & & & & \\
\hline TSE_1 & & 0.64 & & & & & \\
\hline TSE_2 & & 0.74 & & & & & \\
\hline TSE_3 & & 0.78 & & & & & \\
\hline TSE_4 & & 0.78 & & & & & \\
\hline TSE_5 & & 0.92 & & & & & \\
\hline TSE_6 & & 0.86 & & & & & \\
\hline TEC_1 & & & 0.81 & & & & \\
\hline TEC_1 & & & 0.87 & & & & \\
\hline TEC_1 & & & 0.87 & & & & \\
\hline TEC_1 & & & 0.89 & & & & \\
\hline TSI_1 & & & & 0.80 & & & \\
\hline TSI_2 & & & & 0.79 & & & \\
\hline TSI_3 & & & & 0.69 & & & \\
\hline TSC_1 & & & & & 0.70 & & \\
\hline TSC_2 & & & & & 0.75 & & \\
\hline TSC_3 & & & & & 0.79 & & \\
\hline TSC_4 & & & & & 0.77 & & \\
\hline TEl_1 & & & & & & 0.89 & \\
\hline TEl_2 & & & & & & 0.94 & \\
\hline TEl_3 & & & & & & 0.90 & \\
\hline TEP_1 & & & & & & & 0.74 \\
\hline TEP_2 & & & & & & & 0.76 \\
\hline TEP_3 & & & & & & & 0.84 \\
\hline TEP_4 & & & & & & & 0.78 \\
\hline TEP_5 & & & & & & & 0.84 \\
\hline
\end{tabular}


Table 4: Construct Correlations -

Note: Shaded cells show the square root of AVE's for each construct.

\begin{tabular}{|c|c|c|c|c|c|c|c|}
\hline & $\begin{array}{l}\text { Sales } \\
\text { Performance } \\
\text { (SP) }\end{array}$ & $\begin{array}{l}\text { Technology } \\
\text { Self Efficacy } \\
\text { (TSE) }\end{array}$ & $\begin{array}{l}\text { Technology } \\
\text { Competence } \\
\text { (TEC) }\end{array}$ & $\begin{array}{l}\text { Technostress } \\
\text { Inhibitors } \\
\text { (TSI) }\end{array}$ & $\begin{array}{l}\text { Technostress } \\
\text { Creators } \\
\text { (TSC) }\end{array}$ & $\begin{array}{l}\text { Technology } \\
\text { Enabled } \\
\text { Innovation } \\
\text { (TEI) }\end{array}$ & $\begin{array}{l}\text { Technology } \\
\text { Enabled } \\
\text { Performance } \\
\text { (TEP) }\end{array}$ \\
\hline $\begin{array}{l}\text { Sales } \\
\text { Performance } \\
\text { (SP) }\end{array}$ & 0.99 & & & & & & \\
\hline $\begin{array}{l}\text { Technology } \\
\text { Self Efficacy } \\
\text { (TSE) }\end{array}$ & $0.23^{\star * *}$ & 0.79 & & & & & \\
\hline $\begin{array}{l}\text { Technology } \\
\text { Competence } \\
\text { (TEC) }\end{array}$ & 0.02 & 0.02 & 0.86 & & & & \\
\hline $\begin{array}{l}\text { Technostress } \\
\text { Inhibitors } \\
\text { (TSI) }\end{array}$ & 0.05 & $0.16^{\star \star *}$ & $0.31^{* * *}$ & 0.76 & & & \\
\hline $\begin{array}{l}\text { Technostress } \\
\text { Creators } \\
\text { (TSC) }\end{array}$ & $-0.17^{\star \star \star}$ & $-0.20^{\star \star *}$ & -0.04 & $-0.19 * * \star$ & 0.75 & & \\
\hline $\begin{array}{l}\text { Technology } \\
\text { Enabled } \\
\text { Innovation } \\
\text { (TEI) }\end{array}$ & 0.00 & $0.12^{* *}$ & $0.46^{\star \star \star}$ & $0.41^{\star * \star}$ & $-0.21^{\star \star \star}$ & 0.91 & \\
\hline $\begin{array}{l}\text { Technology } \\
\text { Enabled } \\
\text { Performance } \\
\text { (TEP) }\end{array}$ & 0.04 & $0.21^{\star * *}$ & $0.47^{* \star *}$ & $0.33^{\star * *}$ & $-0.11^{\star *}$ & $0.57^{* * *}$ & 0.79 \\
\hline Mean & 3.73 & 7.38 & 3.94 & 3.62 & 2.64 & 3.69 & 3.73 \\
\hline Std. Dev. & 0.82 & 1.55 & 0.64 & 0.53 & 0.65 & 0.72 & 0.68 \\
\hline
\end{tabular}




\subsubsection{Path Model}

We used PLS for testing our hypothesized relationships. The T-statistics for the path coefficients were obtained by bootstrapping generated by two hundred samples, which is the default re-sampling option, to provide reasonable standard error estimates (Chin, 1998). Figure 2 shows the structural model with path co-efficients, significance levels, R-square values, and the factor loadings. Results indicate support for all hypotheses, except H4. That is, we did not find TSE to moderate the relationship between TSC and SP. Instead, we found a significant direct relationship between TSE and SP${ }^{4}$.

We next conducted an analysis to test for possible mediation effects (Baron and Kenny, 1986). We ran a path model that had the following: (1) our hypothesized relationships $\mathrm{H} 1, \mathrm{H} 2, \mathrm{H} 3, \mathrm{H} 5, \mathrm{H} 6$ and H7, (2) a direct relationship between TSE and SP based on the previous step, (3) direct relationships between TSI and TEI, TSI and SP, and TSC and TEP, to test whether the variables TSC and TEl fully or partially mediated the respective relationships. We found significant relationships for (1) and (2). For (3) we found a significant relationship between TSI and TEI. Those between TSC and TEP, and TSI and SP were non-significant. We therefore ran the final model as shown in Figure 3, after removing the (non-significant) TSC -> TEP and TSI -> SP paths. Figure 3 shows the path coefficients, significance and R-square values. We summarize the findings in Table 5.

\footnotetext{
${ }^{4}$ To create a moderating relationship PLS requires a direct path between the moderator variable and the dependent variable.
} 


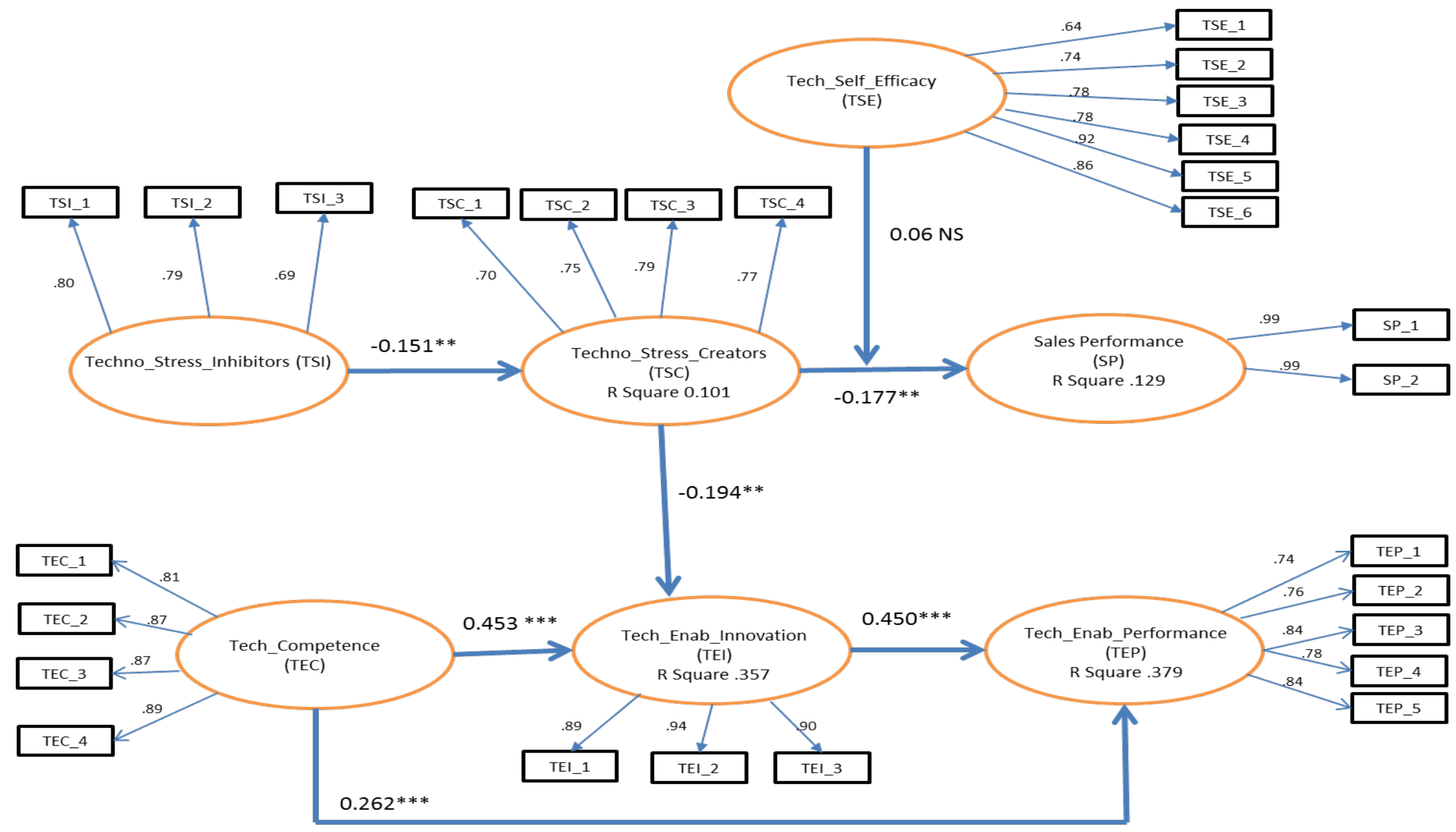

Figure 2: Hypothesized Model [Note: ** Significant at $p<0.01 ; * \star$ Significant at $p<0.05$; * Significant at $p<0.10$, NS Non-significant] 


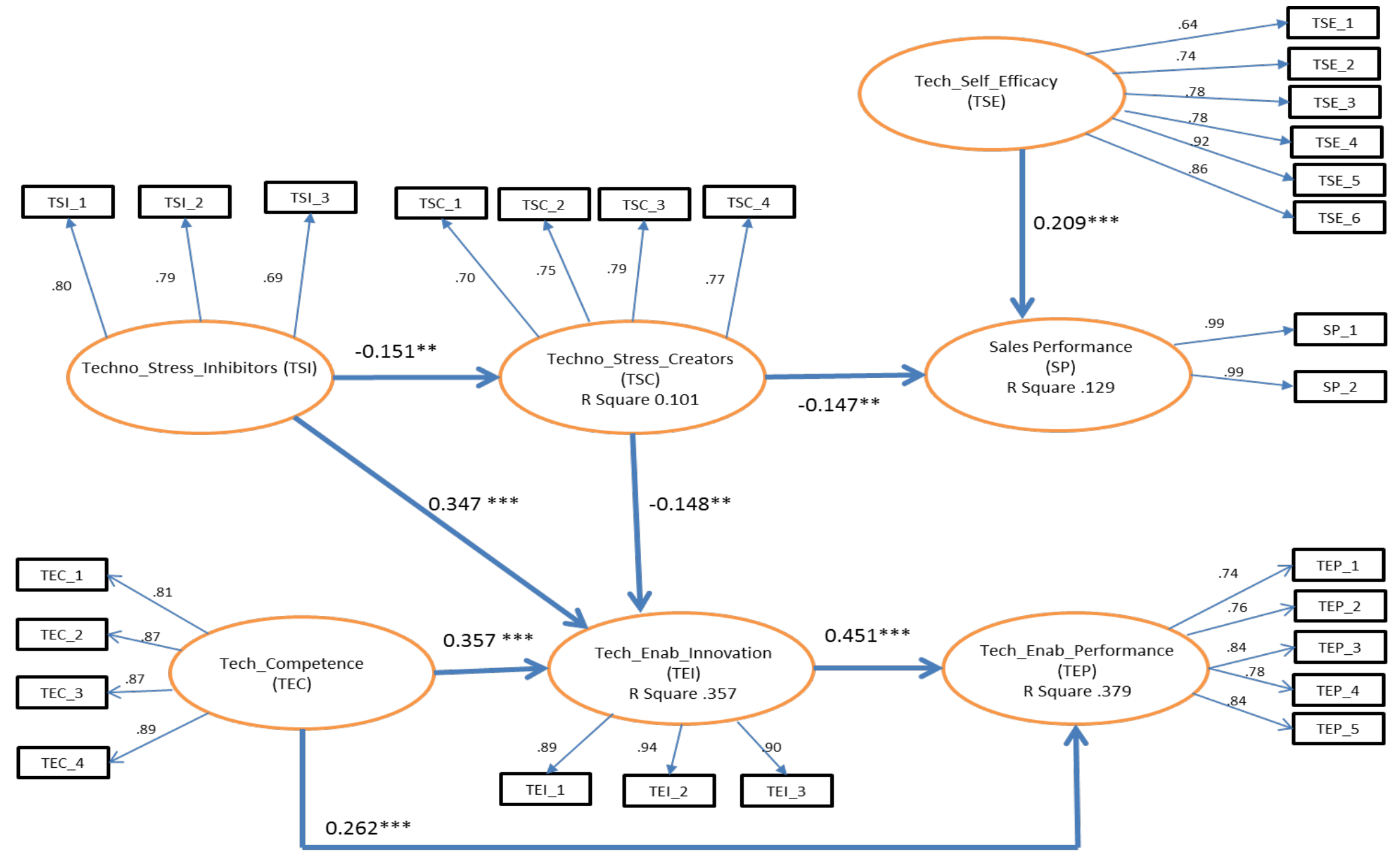

Figure 3: Final Model [Note: ** Significant at $p<0.01$; ** Significant at $p<0.05$; Significant at $p<0.1$ 


\begin{tabular}{|l|c|c|}
\hline \multicolumn{1}{|c|}{ Table 5: Summary of Results } & \multicolumn{1}{|c|}{$\begin{array}{c}\text { Path } \\
\text { Coefficients }\end{array}$} & \\
\hline \multicolumn{1}{|c|}{ Hypotheses } & $-0.147^{\star \star}$ \\
\hline $\begin{array}{l}\text { P1: Technostress Creators (TSC) - Sales } \\
\text { Performance (SP) }\end{array}$ & Supported \\
\hline $\begin{array}{l}\text { H2: Technostress Creators (TSC) - Technology } \\
\text { Enabled Innovation (TEI) }\end{array}$ & $-0.148^{\star \star}$ & Supported \\
\hline $\begin{array}{l}\text { H3: Technology Enabled Innovation (TEI) - } \\
\text { Technology Enabled Performance (TEP) }\end{array}$ & Supported \\
\hline $\begin{array}{l}\text { H4: Technology Self-Efficacy (TSE) moderates the } \\
\text { relationship between Technostress Creators (TSC) } \\
\text { and Sales Performance (SP) }\end{array}$ & $0.451^{\star \star \star}$ \\
\hline $\begin{array}{l}\text { H5: Technostress Inhibitors (TSI) - Technostress } \\
\text { Creators (TSC) }\end{array}$ & $-0.151^{\star \star}$ & Supported \\
\hline $\begin{array}{l}\text { H6: Technology Competence (TEC) - Technology } \\
\text { Enabled Performance (TEP) }\end{array}$ & $0.262^{\star \star \star}$ & Supported \\
\hline $\begin{array}{l}\text { H7: Technology Competence (TEC) - Technology } \\
\text { Enabled Innovation (TEI) }\end{array}$ & $0.357^{\star \star \star}$ & Supported \\
\hline $\begin{array}{l}\text { Technology Self-Efficacy (TSE) - Sales Performance } \\
\text { (SP) }\end{array}$ & $0.209^{\star \star *}$ \\
\hline $\begin{array}{l}\text { Technostress Inhibitors (TSI) - Technology Enabled } \\
\text { Innovation (TEI) }\end{array}$ & $0.347^{\star \star \star}$ & \\
\hline
\end{tabular}

Note: ** Significant at $p<0.01 ; * \star$ Significant at $p<0.05 ;$ * Significant at $p<0.10$ 
As shown in Table 5, H3 was not significant. That is, TSE did not moderate the relationship between TSC and SP, but it had a direct relationship with SP. We note here that TSE is an indicator of how much control the individual feels he or she has over the use of IS. That is, higher TSE can be taken to mean greater perceived control over IS use based on greater belief in one's ability to use IS. The stress literature provides mixed results vis-à-vis the impact of control on the relationship between workload related stress and strains such as satisfaction or anxiety (Jex and Gudanowski, 1992). Whereas perceived job control moderates the relationship between workload related stressors and job satisfaction in some cases (Fox et al., 1995), others have not demonstrated such an effect (Perrewe and Ganster, 1989; O'Driscoll and Beehr, 2000). We also find that employees' belief that they have control over their jobs directly impacts the strain variables from work demand stressors, that is, reduces anxiety and increases job satisfaction (Spector, 1985), rather than moderating the relationship between stressors and strain. From the sales literature, we find that when the salesperson does not believe in her or ability to use IS, his or her productivity decreases (Bush et al., 2007). Technology self-efficacy, which is a belief-oriented and intrinsic concept, can thus improve sales performance by facilitating greater inherent control over IS use. We also found that that TSC partially mediates the relationship between TSI and TEI, that is increase in TSI is directly associated with increase in TEl. This can be explained contextually in that research has shown that organizational support to salespeople may enhance intrinsic orientation by providing them with a stronger sense of control, and plays an important role in their creating solutions of value for customers (e.g. Heskett et al., 1994). Therefore, it can be expected to contribute positively to innovation (Deci and Ryan, 1985; Ryan et al., 1983). TSI, representing a set of organizational support mechanisms for salespeople, may thus enhance the salesperson's ability to use technology to innovate. Also, more generally, the link between TSI and TEI can be explained as that between a situational factor and an individual outcome, as explained by the Transaction Model (Lazarus 1966, Ragu-Nathan et al 2008).

\subsubsection{Control Variables}

We controlled for the effects of three variables - education, organizational tenure and professional tenure - on SP and TEP. Greater levels of education are associated with greater perceived ease of use with respect to IS (Igbaria and Parasuraman, 1989; Agarwal and Prasad, 1999) and therefore might be expected to influence the individual's ability to use IS in work tasks. We expected education levels to have a positive association with TEP. Greater organizational tenure increases the individual's ability to navigate organizational policy changes, 
such as, as pertinent to our study, those related to expectations for IS use for work (RaguNathan et al., 2008). Therefore it might be expected to have a positive relationship to TEP. Professional tenure has been shown to be associated with higher levels of performance (e.g. Bartkus et al., 1989; Churchill et al., 1985), based on which we expected higher levels of SP to be associated with higher tenure in the sales function. We measured education as High school $=1$, 2-year college $=2$, bachelor level $=3$ and graduate level $=4$, and organizational tenure and professional tenure as number of years. We found (Table 5, Appendix) that education levels were positively related with TEP (non-significant relationship with SP), organizational tenure has no significant relationship with either SP and TEP, and professional tenure in the sales function had a positive relationship with SP (non-significant relationship with TEP).

\section{CONTRIBUTIONS AND LIMITATIONS}

The paper develops an understanding of the phenomenon of technostress in the context of IS use by sales/marketing professionals. It incorporates the context by - (1) examining relationships of interest between key constructs identified in the received literature on technostress (i.e. technostress creators and technostress inhibitors), and constructs salient to the professional sales area (i.e. sales performance, technology-enabled performance, technology-enabled innovation, technology self- efficacy); and (2) contributing to both literatures that inform the area of study (i.e. technostress and technology adoption by sales/marketing professionals). We reflect on the paper's theoretical contributions, implications for practice and limitations below.

\subsection{Contributions to Theory}

First, we demonstrate that technostress creating conditions impair innovation and task performance that is mediated through IS, in addition to reducing overall work performance of the individual. Thus the phenomenon of technostress can embody or manifest as adverse effects on outcomes that are technology enabled as well as broader outcomes of the overall performance in the role (in this case the sales person's role). In looking at technology-enabled innovation and performance, and at broader sales performance as the dependent variables, the study furthers current literature (e.g. Ragu-Nathan et al., 2008; Ayyagari et al., 2011) that reports on psychological and physical outcomes such as job commitment, job satisfaction and exhaustion.

Second, then, we present possible methods for counterbalancing these adverse effects. We identify technology competence as a means to increase technology enabled innovation and 
technology enabled performance, offsetting their reduction by technostress creators. We further identify technology self-efficacy and technostress inhibitors, respectively, as potential means to increase sales performance and reduce technostress creators. We thus find the existence of two types of ways for addressing the adverse impacts of technostress on performance. The first, characterized by technology competence, represents the traditional efforts-based aspect wherein the individual's ability to use IS with ease, positively associates with their felicity in accomplishing technology-enabled innovation and performance, and through that, counters the impact of technostress creators on them. The second, characterized by technology self-efficacy and technostress inhibitors, signifies efforts that are more belief/motivation or empowermentbased and that could foil broader negative performance impacts of technostress. That is, the individual's belief in being able to use IS counters the negative impact of technostress creators on overall sales performance. Similarly organizational mechanisms that empower the individual to use IS in a more informed manner, reduce technostress creators and through that, its negative impact on sales performance. To the best of our understanding, this is the first study to suggest that while the traditional technology competence/ability to use IS route can counter those performance impacts of technostress creators that are technology enabled, more motivational/belief and empowerment-related means such as technology self-efficacy and technostress inhibitors are called for to address their impacts on broader performance. Both types of mechanisms are thus required, to address the impacts of technostress creators on performance. We believe that this finding is theoretically important and introduces richness and nuance in the emerging technostress literature.

Third, we integrate ideas from social cognitive theory, technostress and the sales literatures to theoretically lay out and empirically examine a role for technology self-efficacy as a factor that increases sales performance, countering its decrease due to technostress creators. Considering technology-self efficacy furthers understanding of technostress by highlighting that the individual's belief's about ability to use IS will influence response to stressful situations that s/he encounters due to IS use, a perspective missing in literature. The study thus broadens the theoretical ambit of technology self-efficacy in the technostress phenomenon. In considering technostress inhibitors, our study demonstrates that mechanisms such as literacy facilitation and involving sales professionals upfront while introducing new applications can reduce technostress creators. Although IS related training is regarded as a typical mechanism for assisting managers with new applications, our results point to the particular importance of increased understanding about applications and the rationale for and expected benefits from 
their adoption and use, as an additional and effective mechanism for reducing the negative effects of technostress.

Fourth, it is important at this point to discuss the particular context of our study and similar contexts for transferability of our findings. The sales context is distinctive in that requirements for effectively accomplishing critical tasks (such as contact management, for instance) through the use of complex IS (such as ACT!), co-exist with expectations of overall performance in a role that is primarily relationship oriented. Though use of IS is becoming increasingly important for the sales professional, the nature of the job still largely and inherently involves person-toperson communication. Our results show that even as the individual tries to cope with the immediate negative impacts of technostress on IS-mediated tasks, he or she is subject to the broader effect of technostress creators on overall performance. Moreover, while customary technology competence building efforts such as increasing ability to use IS can alleviate the former, more empowering mechanisms such as increasing the individual's self-efficacy with IS and mechanisms for supporting informed IS use, are called for, for reducing the latter. These findings, which the context of this study has enabled us to highlight, are theoretically new and can be extended to a broad range of service industries that have similar characteristics and that have been subject to recent and widespread computerization, such as frontline functions in hospitality, healthcare, banking, and increasingly now, higher education. The services domain thus represents a potentially interesting application/extension for the findings of this paper.

Fifth, this paper offers three theoretical contributions to the professional sales literature. One, it highlights the importance of technostress in the context of the sales professional's ongoing use of IS, and shows it to be a possible reason for reduced performance as an (unintended) effect of use of IS, theoretically extending the IS-sales/marketing literature that focuses on the sales professional's job stress and turnover during initial IS implementation/adoption (Speier and Venkatesh, 2002). We find it important to note that while the professional sales literature has discussed variables such as perceived usefulness as antecedents of IS use, the role of negative cognitions such as technostress in effecting IS use related outcomes has not been examined. Given existing mixed findings regarding the impact of sales technologies use on the performance of the sales professional (Ahearne and Rapp, 2010), technostress represents a promising domain for further exploration. Two, we highlight the importance of technologyenabled innovation in better understanding how technostress creators impact technologyenabled performance. While the importance of technology enabled innovation has increased, 
sales professionals have historically preferred to innovate in the area of customer interactions/solutions, rather than in IS use. Our findings caution that technostress creators can reduce the extent to which the sales professional innovates with technology, in turn negatively impacting his or her performance at technology enabled tasks. Three, while technology selfefficacy has been found to positive impact extent of IS use by sales professionals, in the context of newly implemented sales IS, the current study reveals a more far-reaching impact, namely increased sales performance, in the context of on-going use of existing sales IS.

\subsection{Implications for Practice}

A number of customer-facing and service-oriented functions and roles have seen increasing numbers of IS mediated tasks in recent years. At the same time, rates of failure of such applications due to non-use or insufficient have been high IS (Erffmeyer and Johnson, 2001). Given the struggles in appropriating benefits from the use of sales force applications (Ahearne et al., 2004), and strategically important expectations from their use (Sarin et al., 2010), insights into how technology-related stress relates to technology enabled innovation and performance, and sales performance, are critical to improving the practical application of these IS. The paper suggests that adding technology responsibilities could be associated with technostress and lead to deteriorating performance. While increasing the individual's competence for using IS can partially counter that deterioration, increasing technology self-efficacy, IS related understanding and literacy, training and help desk support, and involvement in IS decisions that affect their tasks and workflows, are also crucial. In particular, it is important to go beyond standard training mechanisms, and ensure, through continuing education, involvement, confidence/belief building, and technical assistance, that sales professionals, and in general professionals in frontline or customer-interfacing careers, understand why specific technologies are implemented, how they can be used and what functionalities they beget. Moreover, given that such professionals typically may not be physically located internally in the organization but remotely housed, it is important for the organization to make them aware of such support mechanisms as might exist. Finally, the paper also provides an instrument to assess levels of technostress among sales professionals through the "technostress creators" construct.

\subsection{Limitations}

In terms of limitations to our study, firstly, it was conducted in a limited setting of three firms, all in the institutional/business-to-business product domain. Further research can show the robustness of findings across different settings such business-to-consumer sales, services 
sales, other service industries and so forth. Second, subjective, self-report measures of performance were used. Future research that utilizes objective performance measures would be useful. Third, future research also needs to consider longitudinal studies that measure technostress over time and in tandem with interventions in the form of inhibiting factors identified in our study.

\section{CONCLUSION}

The phenomenon of technostress is emerging and not yet fully understood. And yet, with pervasiveness of IS in many frontline and customer-facing processes, it is reasonable to expect that this "dark" phenomenon would dampen expected benefits from their use in these processes. Focusing on the professional sales context, this paper examines the negative manifestations of stress creating aspects of IS use, as adverse effects on the individual's technology-enabled innovation, technology-enabled performance, and overall performance. We also highlight potential mechanisms to offset these impacts. The paper theoretically extends the current technostress literature to highlight performance impacts of technostress, and contributes more generally to the up-and-coming area that is beginning to examine negative consequences due to use of IS.

\section{REFERENCES}

Agarwal, R. and Prasad, J. (1999) Are individual differences germane to the acceptance of new information technologies?, Decision sciences 30(2): 361-391.

Ahearne, M. and Rapp, A. (2010) The role of technology at the interface between salespeople and consumers, Journal of Personal Selling and Sales Management 15(2): 111-130.

Ahearne, M., Jones, E., Rapp, A. and Mathieu, J. (2008) High Touch through High Tech: The Impact of Salesperson Technology Usage on Sales Performance via Mediating Mechanisms, Management Science 54 (4): 667-685.

Ahearne, M., Srinivasan, N. and Weinstein, L. (2004) Effect of Technology on Sales Peformance: Progressing from Technology Acceptance to Technology Usage and Consequence, Journal of Personal Selling and Sales Management 24(4): 297-310.

Amabile, T., Conti, R., Coon, H., Lazenby, J. and Herron, M. (1996) Assessing the Work Environment for Creativity, Academy of Management Journal (39): 1154 - 1184.

Arnetz, B.B. and Wiholm, C. (1997) Technological Stress: Psychophysiological symptoms in modern offices, Journal of psychosomatic Research 43(1): 35-42.

Ayyagari, R., Grover, V. and Purvis, R. (2011) Technostress: technological antecedents and implications. MIS Quarterly 35(4): 831-858. 
Bandura, A. (1982) Self-efficacy mechanism in human agency. American Psychologist 372: 122 $-147$.

Barker, R., Gohmann, S., Guan, J. and Foulds, D. (2009) Why is my Sales Force Automation Failing, Business Horizons 52: 233-241.

Baron, R.M. and Kenny, D.A. (1986) The Moderator Mediator Variable Distinction in Social Psychological-Research: Conceptual, Strategic, and Statistical Considerations, Journal of Personality and Social Psychology 51(6): 1173-1182.

Bartkus, K.R., Peterson, M.F. and Bellenger, D.N. (1989) Type A behavior, experience, and salesperson performance, The Journal of Personal Selling and Sales Management: 11-18.

Bartlett, V. (1995) Technostress and Librarians. Library Administration and Management, 9(4): 226-30.

Beehr, T. (1998) An organizational psychology meta-model of occupational stress. C. Cooper, (ed.) Theories of organizational stress, Oxford University Press: New York, pp.6-27.

Behrman, D. and Perreault, W. (1984) A Role Stress Model of the Performance and Satisfaction of Industrial Salespersons, Journal of Marketing 48(4): 9-21.

Bharadwaj, S. and Menon, A. (2000) Making Innovation Happen in Organizations: Individual Creativity Mechanisms, Organizational Creativity Mechanisms or Both?, Journal of Product Innovation Management 17:424-434.

Brockner, J. (1988) Self-esteem at work: Research, Theory, and Practice, Lexington MA: Lexington Books.

Brod, C. (1982) Managing Technostress: Optimizing the Use of Computer Technology, Personnel Journal 61(10): 753-57.

Brown, S., Jones, E. and Leigh, T. (2007) The Attenuating Effect of Role Overload on Relationships Linking Self-efficacy and Goal Level to Work Performance, Journal of Applied Psychology 90(5): 972-79.

Buehrer, R., Senecal, S. and Pullins, E. (2005) Sales force technology usage-reasons, barriers, and support: An exploratory investigation, Industrial Marketing Management, 34(4): 389-398.

Bush, A.J., Bush, V.D., Orr, L.M. and Rocco, R.A. (2007) Sales technology: Help or hindrance to ethical behaviors and productivity?, Journal of Business Research 60(11): 1198-1205.

Chin, W. (1998) Issues and Opinion on Structural Equation Modeling, MIS Quarterly 22(1): 716.

Chonko, L.B., Loe, T.N., Roberts, J.A. and Tanner, J.F. (2002) Sales performance: Timing of measurement and type of measurement make a difference, Journal of Personal Selling \& Sales Management 20(1): 23-36. 
Churchill Jr, G.A., Ford, N.M., Hartley, S.W. and Walker Jr, O.C. (1985) The determinants of salesperson performance: a meta-analysis, Journal of Marketing Research: 103-118.

Compeau, D. and Higgins, C. (1995) Computer self-efficacy: development of a measure and initial test, MIS Quarterly: 189 - 211.

Compeau, D. and Higgins, C. (1995) Application of social cognitive theory to training for computer skills, Information Systems Research 6(2): 118 - 143.

Compeau, D., Higgins, C. and Huff, S. (1999) Social cognitive theory and individual reactions to computing technology: a longitudinal study, MIS Quarterly 23(2): 145 - 158.

Cooper, C., Dewe, P. and O'Driscoll, M. (2001) Organizational stress: a review and critique of theory, research, and applications, Thousand Oaks, CA: Sage, pp.270.

Crosby, L., Evans, K. and Cowles, D. (1990) Relationship Quality in Services Selling: An Interpersonal Influence Perspective, Journal of Marketing 54(3): 68-83.

Day, G.A. and Van den Blute, C. (2002) Superiority in customer relationship management: Consequences for competitive advantage and performance, Working Paper, The Wharton School, University of Pennsylvania 1-49.

Deci, E.L. (1972) The effects of contingent and non-contingent rewards and controls on intrinsic motivation, Organizational Behavior and Human Performance 8(2): 217-229.

Deci, E.L., and Ryan, R.M. (1985) Self-Determination: John Wiley \& Sons, Inc..

DiLiello, T. and Houghton, J. (2008) Creative Potential and Practiced Creativity: Identifying Untapped Creativity in Organizations, Creativity and Innovation Management 17(1): 37-46.

Eggert, A. and Serdaroglu, M. (2011) Exploring the Impact of Sales Technology on Salesperson Performance: A Task-Based Approach, Journal of Marketing Theory and Practice 19(2): 169186.

Ennis, L.A. (2005) The evolution of technostress, Computers in Libraries 25(8): 10-12.

Erffmeyer, R. and Johnson, D. (2001) An Exploratory Study of Sales Force Automation Practices: Expectations and Realities, Journal of Personal Selling and Sales Management 21(2): 167-175.

Fenlason, K.J. and Beehr, T.A. (1994) Social support and occupational stress: Effects of talking to others, Journal of Organizational Behavior 15(2): 157-175.

Flynn, B.B., Huo, B. and Zhao, X. (2010). The impact of supply chain integration on performance: A contingency and configuration approach, Journal of Operations Management 28(1): 58-71.

Fornell, C. and Larcker, D. (1981) Evaluating Structural Equation Models with Unobservable Variables and Measurement Error, Journal of Marketing Research (18): 39-50. 
Fox, M., Dwyer, D. and Ganster, D. (1995) Effects of stressful job demands and control of physiological and attitudinal outcomes in a hospital setting, Academy of Management Journal 36: $289-318$.

Frone, M.R., Russell, M. and Cooper, M.L. (1995) Relationship of work and family stressors to psychological distress: The independent moderating influence of social support, mastery, active coping, and self-focused attention. In R. Crandall and P.L. Perrewé (eds.) Occupational Stress: A Handbook, 129-150. Washington, DC: Taylor \& Francis, 1995.

Fu, F., Richards, K., Hughes, D. and Jones, E. (2010) Motivating Salespeople to Sell New Products: The Relative Influence of Attitudes, Subjective Norms, and Self-Efficacy, Journal of Marketing 74(6): 61-76.

Geiger, S. and Turley, D. (2006) The Perceived Impact of Information Technology on Salespeople's Relational Competencies, Journal of Marketing Management 22: 827-851.

Goolsby, J. (1992) Theory of Role Stress in Boundary Spanning Positions of Marketing Organizations, Journal of the Academy of Marketing Science 20(2): 155-165.

Harding, D., Cheifetz, D., DeAngelo, S, Ziegler, E. (2004) CRM's silver lining, Marketing Mangement 13(2): 10613846.

Heskett, J.L. and Schlesinger, L.A. (1994) Putting the service-profit chain to work, Harvard Business Review 72(2): 164-174.

Holt, S. (1998) Sales Force Automation Ramps Up, InfoWorld 20(29): 38.

Homburg, C., Wieseke, J. and Kuehnl, C. (2009) Social influence on salespeople's adoption of sales technology: A multilevel analysis, Journal of the Academy of Marketing Science 38(2): 159-168.

House, J. (1981). Work stress and social support. Reading, MA: Addison-Wesley

Hunter, G. and Perrault, W. (2006) Sales Technology Orientation, Information Effectiveness and Sales Performance, Journal of Personal Selling and Sales Management 26(2): 95-113.

Hunter, G. and Perrault, W. (2007) Making Sales Technology Effective, Journal of Marketing 26(2): 16-34.

Igbaria, M. and Parsuraman, S. (1989) A path analytic study of individual characteristics, computer anxiety, and attitudes towards microcomputers, Journal of Management 15(3): 373388.

Im, S. and Workman Jr, J. (2004) Market Orientation, Creativity, and New Product Performance in High-Technology Firms, Journal of Marketing 68: 114-132.

Ingram, T.N., LaForge, R.W. and Leigh, T.W. (2002) Selling in the new millennium: A joint agenda, Industrial Marketing Management 31(7): 559-567.

Ivancevich, J.M. and Matteson, M.T. (1980) Stress and work: A managerial perspective, Dallas: Foresman. 
Jackson, S. and Schuler, R. (1985) A meta-analysis and conceptual critique of research on role ambiguity and role conflict in work settings, Organizational Behavior and Human Decision Processes 36: 16-78.

Jasperson, J. Carter, P.E. and Zmud, R.W. (2005) A Comprehensive Conceptualization of the Post-Adoptive Behaviors Associated with Information Technology Enabled Work Systems, MIS Quarterly 29(3): 252-557.

Jelinek, R. (2013) All pain, no gain? Why adopting sales force automation tools is insufficient for performance improvement, Business Horizons, 56(5): 635-642.

Jex, S.M. and Beehr, T.A. (1991) Emerging theoretical and methodological issues in the study of work-related stress, Research in Personnel and Human Resources Management 9: 311-365.

Jex. S. and Gudaowski, D. (1992) Efficacy beliefs and work stress: An exploratory study, Journal of Organizational Behavior 13: 509-517.

Jimmieson, N. and Terry, D. (1998) The role of informational control in the stress strain relationship; 13th Annual Conference of the Society for Industrial and Organizational Psychology.

Johns, G. (2006) The Essential Impact of Context on Organizational Behavior, Academy of Management Review 31(2): 386-408.

Jones, E., Chonko L., Rangarajan D., and Roberts, J. (2007) The role of overload on job attitudes, turnover intentions and salesperson performance, Journal of Business Research, 60 (July): 663-671.

Jones, E., Sundaram, S. and Chin, W. (2002) Factors leading to sales force automation use: A longitudinal analysis, Journal of Personal Selling and Sales Management 22(3): 145-156.

Jones, F. and Fletcher, B.C. (1996) Job Control and Health, Handbook of work and health psychology, pp.33-50.

Kahn, R., Wolfe, D.M., Quinn, R.P. and Snoek, J.D. (1981) Organizational Stress: Studies in Role Conflict and Ambiguity, FL: Krieger, Malabar.

Kahn, R. and Byosiere, P. (1992) Stress in organizations, (ed.) Handbook of Industrial and Organizational Psychology, Consulting Psychologists Press: M. Dunnette, L. Hough pp.571650.

Karasek, R. (1979) Job demands, job decision latitude and mental strain: Implications for job redesign, Administrative Science Quarterly 24: 285-308.

Krishnan, B.C., Netemeyer, R.G., and Boles, J.S. (2002) Self-efficacy, competitiveness, and effort as antecedents to salesperson performance, Journal of Personal Selling and Sales Management, 22 (4): 285-295.

Kumar, R. and Uzkurt, C. (2010) Investigating the effects of self-efficacy on innovativeness and the moderating impact of cultural dimensions, Journal of International Business \& Cultural Studies 4: 1-15. 
Kupersmith, J. (1992) Technostress and the reference librarian, Reference Services Review 20(2): 7-50.

Lazarus, R. (1991) Psychological stress in the workplace, Journal of Social Behavior and Personality 6: 1-13.

Lazarus, R.S. (1966) Psychological Stress and the Coping Process, New York: McGraw-Hill.

Lee A.S. and Baskerville R.L., (2003) "Generalizing generalizability in information systems research", Information Systems Research 14(3): 221-243

Lindell, M.K. and Whitney, D.J. (2001) Accounting for common method variance in crosssectional research designs, Journal of Applied Psychology 86(1): 114.

Malhotra, N.K., Kim, S. S. and Patil, A. (2006) Common method variance in IS research: A comparison of alternative approaches and a reanalysis of past research, Management Science 52(12): 1865-1883.

Mathieu, J., Ahearne, M. and Taylor, S. (2007) A Longitudinal Cross-Level Model of Leader and Salesperson Influences on Sales Force Technology Use and Performance, Journal of Applied Psychology 92(2): 528-537.

McGrath, J.E. (1976) Stress and behavior in organizations, Handbook of industrial and organizational psychology pp.1351-1396.

Moncrief, W. (1986) Selling Activity and Sales Position Taxonomies for Industrial Salesforces, Journal of Marketing Research 23(3): 261-70.

Morgan, R. and Hunt, S. (1994) The Commitment-Trust Theory of Relationship Marketing, Journal of Marketing 58(3): 20-39.

Nelson, D. (1990) Individual adjustment to information-driven technologies: a critical review, MIS Quarterly: 79-98.

Nelson, D. and Kletke, M. (1990) Individual adjustment during technological innovation: A research framework. Behavior and Information Technology, 9(4): 257-271.

Nelson, D.L. and Kletke, M.G. (1990) Individual adjustment during technology innovation: A research framework, Behavior and Information Technology 9(4): 257-271.

Nunnally, J. (1978) Psychometric Theory, New York: McGraw-Hill.

O'Driscoll, M. and Beehr, T. (2000) Moderating effects of perceived control and need for clarity on the relationship between role stressors and employee affective reactions, Journal of Social Psychology 140: 91-113.

Onyemah, V., Swain, S.D. and Hanna, R. (2010) A social learning perspective on sales technology usage: Preliminary evidence from an emerging economy, Journal of Personal Selling \& Sales Management 30(2): 131-142.

Orlikowski W.J., Iacono C.S. (2001) "Research commentary: Desperately seeking the "IT" in IT 
research - A call to theorizing the IT artifact", Information Systems Research. 12(2):121-134

Paulraj, A., Lado, A. and Chen, I. (2008) Inter-organizational communication as a relational competency: Antecedents and performance outcomes in collaborative buyer-supplier relationships, Journal of Operations Management 26: 45-64.

Perrewe, P. and Ganster, D. (1989) The impact of job demands and behavior control on experienced job stress, Journal of Organizational Behavior 10: 213-229.

Pierce, J., Gardner, D., Dunham, R. and Cummings, L. (1993) Moderation by organizationbased self esteem of role of condition-employee response relationships, Academy of Management Journal 36: 271-288.

Plouffe, C.R., Nelson, Y.H. and Beuk, F. (2013) Testing an Enhanced, Process-Based View of the Sales Process, Journal of Personal Selling and Sales Management 33(2): 141-164.

Podsakoff, P.M., MacKenzie, S.B., Lee, J.Y. and Podsakoff, N.P. (2003) Common method biases in behavioral research: A critical review of the literature and recommended remedies, Journal of Applied Psychology 88: 879-903.

Pullins, E.B. (2001) An Exploratory Investigation of the Relationship of Sales Force Compensation and Intrinsic Motivation, Industrial Marketing Management 30(5): 403-413

Ragu-Nathan, T., Tarafdar, M., Ragu-Nathan, B.S. and Tu, Q. (2008) The consequences of technostress for end users in organizations: Conceptual development and empirical validation, Information Systems Research 19(4): 417-433.

Rangarajan, D., Jones, E. and Chin, W. (2005) Impact of Sales Force Automation on Technology Usage among Salespeople, Industrial Marketing Management 34: 345-354.

Rapp, A., Agnihotri, R. and Forbes, L. (2008) The Sales Force Technology-Performance Chain: The Role of Adaptive Selling and Effort, Journal of Personal Selling and Sales Management 28(4): 335-350.

Rich, G. (2002) The Internet: Boom or Bust to Sales Organizations?, Industrial Marketing Management 18: 300-387.

Ritter, T. and Walter, A. (2004) Matching high-tech and high-touch in supplier-customer relationships, European Journal of Marketing 40(3/4): 292-310.

Rizzo, J.R., House, R.J. and Lirtzman, S.I. (1970) Role conflict and ambiguity in complex organizations, Administrative Science Quarterly 15(2): 150-163.

Rossiter, J. R. (2002). The C-OAR-SE procedure for scale development in marketing, International Journal of Research in Marketing 19(4): 305-335.

Rodriguez, M. and Honeycutt, E.D. (2011) Customer relationship management (CRM)'s impact on B to B sales professionals collaboration and sales performance, Journal of Business-toBusiness Marketing 18(4): 335-356. 
Ryan, R.M., Mims, V. and Koestner, R. (1983) Relation of reward contingency and interpersonal context to intrinsic motivation: A review and test using cognitive evaluation theory, Journal of Personality and Social Psychology 45(4): 736.

Sainfort, P. (1990) Job design predicators of stress in automated office, Behavior and Information Technology 9(1): 3-16.

Sarin, S., Sego, T., Kohli, A. and Challagalla, G. (2010) Characteristics that enhance training effectiveness in implementing technological change in Sales Strategy: A Field-Based Exploratory Study, Journal of Personal Selling and Sales Management 15(2): 143-156.

Saxe, R. and Weitz, B. (1982) The SOCO Scale: A Measure of the Customer Orientation of Salespeople, Journal of Marketing Research 19(3): 343-351.

Schaubroeck, J. and Merritt, D.E. (1997) Divergent effects of job control on coping with work stressors: The key role of self-efficacy, Academy of Management Journal 40(3): 738-754.

Scheck. C., Knicki, A. and Davy, J. (1997) Testing mediating processes between work stressors and subjective well being, Journal of Vocational Behavior 50: 96-123.

Shu, Q., Tu, Q. and Wang, K. (2011) The impact of computer self-efficacy and technology dependence on computer-related technostress: A social cognitive theory perspective, International Journal of Human-Computer Interaction 27(10): 923-939.

Singh, J (1998) Striking a Balance in Boundary-Spanning Positions: An Investigation of Some Unconventional Influences of Role Stressors and Job Characteristics on Job Outcomes of Salespeople, Journal of Marketing 62(3): 69-86.

Sojka, J. and Deeter-Schmelz, D. (2008) Need for cognition and affective orientation as predictors of sales performance: An investigation of main and interaction effects, Journal of Business and Psychology 22(3): 179-190.

Spector, P.E. (1985) Measurement of human service staff satisfaction: Development of the Job Satisfaction Survey, American Journal of Community Psychology 13(6): 693-713.

Spector, P.E. (1988) Development of the Work Locus of the Control Scale, Journal of Occupational Psychology 61: 335-340.

Speier, C. and Venkatesh, V. (2002) The Hidden Minefields in the Adoption of Sales Force Automation Technologies, Journal of Marketing 66: 98-111.

Storbacka, K., Polsa, P. and Sääkjärvi, M. (2011) Management Practices in Solution Sales: A Multilevel and Cross-Functional Framework, Journal of Personal Selling and Sales Management 31(1): 35-54.

Sun, B. (2006) Technology innovation and implications for customer relationship management, Marketing Science 25(6): 594-597.

Sundaram, S., Schwarz, A., Jones, E. and Chin, W. (2007) Technology use on the front line: how information technology enhances individual performance, Journal of Academy of Marketing Science 35: 101-112. 
Tanner, J.F., Ahearne, M., Leigh, T.W., Mason, C. and Moncrief, W. (2005) CRM in salesintensive organizations: A review and future directions, Journal of Personal Selling and Sales Management 25(2): 170-180.

Tarafdar, M., Tu, Q. and Ragu-Nathan, T. (2010) Impact of technostress on end-user satisfaction and performance, Journal of Management Information Systems 27(3): 303-334.

Tarafdar, M., Tu, Q., Ragu-Nathan, B.S. and Ragu-Nathan, T.S. (2007) The impact of technostress on role stress and productivity, Journal of Management Information Systems 24(1): 301-328.

Tarafdar, M., Tu, Q., Ragu-Nathan, T. and Ragu-Nathan, B.S. (2011) Crossing to the dark side: examining creators, outcomes, and inhibitors of technostress, Communications of the ACM 54(9), 113-120.

Taylor-West, P. and Saker, J. (2012) Computer assisted sales processes in automotive retailing, International Journal of Retail and Distribution Management 40(7); 493-509.

Torkzadeh, G. and Doll, W. (1999) The Development of a Tool for Measuring the Perceived Impact of Information Technology on Work, OMEGA International Journal of Management Science 27(3): 327-339

Tsui A.S. (2007) "From homogenization to pluralism: International management research in the academy and beyond", Academy of Management Journal. 50(6):1353-1364

Tu, Q., Wang, K. and Shu, Q. (2005) Computer-related technostress in China, Communications of the ACM 48(4): 77-81.

Van Fleet, C. and Wallace, D.P. (2001) Virtual libraries-Real stress: Change at the reference desk, Advances in Library Administration and Organization 18: 1-44.

Venkatesh, V. and Davis, F. (1996) A model of the antecedents of perceived ease of use: development and test, Decision Sciences 27: 451 - 482.

Walter, A. and Ritter, T. (2004) Information technology competence and value creation in supplier-customer relationships, Journal of Relationship Management, 3(4): 45-59.

Walter, A., Ritter, T. and Gemüden. H. G.. (2001) Value Creation in Buyer: Seller Relationships, Industrial Marketing Management 30(4): 365-377.

Wang, K., Shu, Q. and Tu, Q. (2008) Technostress under different organizational environments: An empirical investigation, Computers in Human Behavior 24(6): 3002-3013.

Wang, G. and Netemeyer, R. (2004) Salesperson Creative Performance: Conceptualization, Measurement, and Nomological Validity, Journal of Business Research 57(8): 805-813.

Wastell, D. and Newman, N. (1993) The behavioral dynamics of information system development: a stress perspective, Accounting Management and Information Technology 3: 121-148. 
Weil, M. and Rosen, L. (1997) TechnoStress: Coping with Technology @work @home @play, New York: J. Wiley, pp.240.

Weitz, B.A. (1978) "The Relationship Between Salesperson Performance and Understanding of Customer Decision Making", Journal of Marketing Research 15(50): 1 -16.

Wetzels, M., Odekerken-Schroder, G. and Van Oppen, C. (2009) Using PLS Path Modeling for Assessing Hierarchical Construct Models: Guidelines and Empirical Illustration, MIS Quarterly 33(1): 177 - 195.

Whetten DA (2009) "An examination of the interface between context and theory applied to the study of Chinese organizations", Management Organization Review, 5(1):29-55.

Zallocco, R., Pullins, E. and Mallin, M. (2009) A re-examination of B2B sales performance, Journal of Business \& Industrial Marketing 24(7/8): 598-610. 
APPENDIX

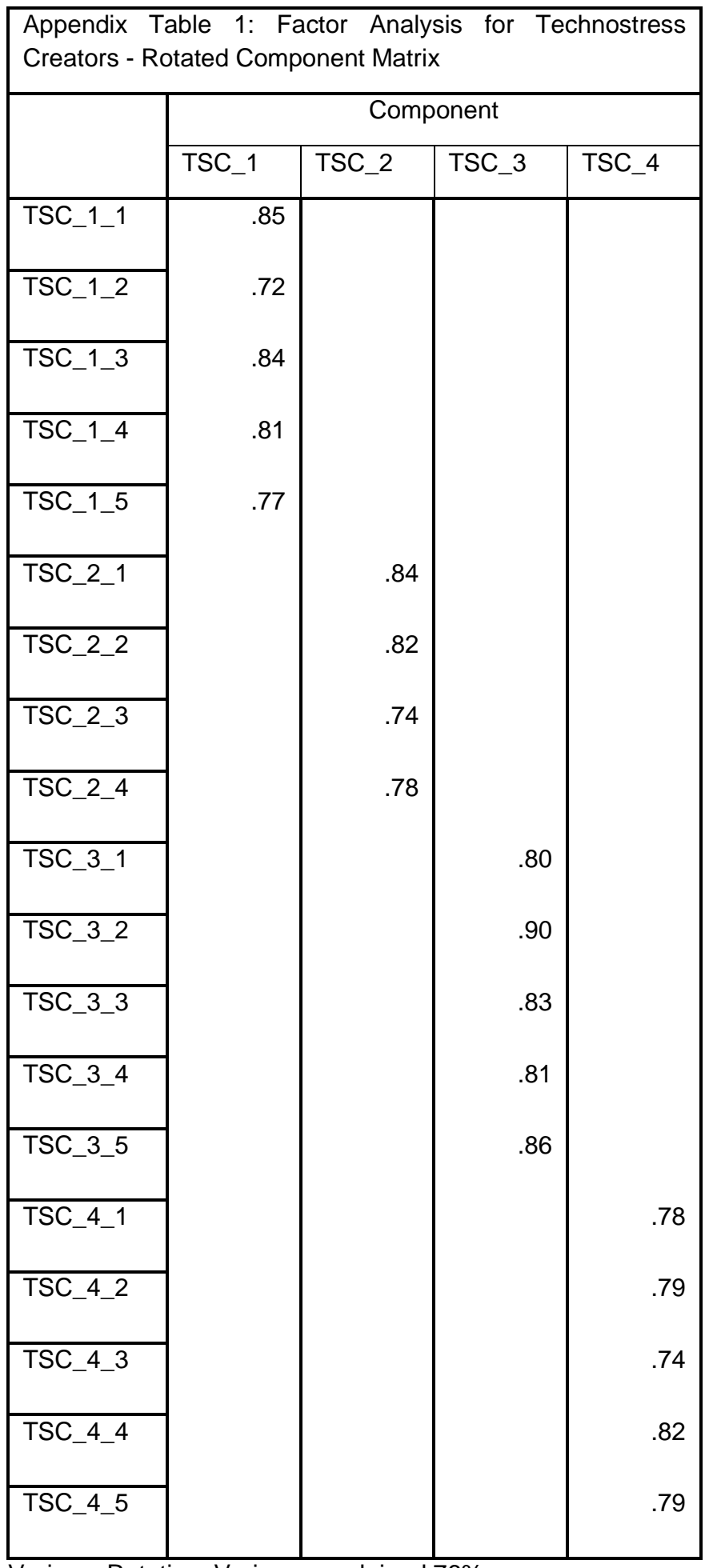

Varimax Rotation, Variance explained 76\% 
KMO: .90 , Bartlett's Test of Sphericity chi-square $=321, \mathrm{df}=171$, significance $=0.000$

\begin{tabular}{|c|c|c|c|}
\hline \multicolumn{4}{|c|}{$\begin{array}{l}\text { Appendix Table 2: Factor Analysis for Technostress } \\
\text { Inhibitors - Rotated Component Matrix }\end{array}$} \\
\hline & \multicolumn{3}{|c|}{ Component } \\
\hline & 1 & 2 & 3 \\
\hline TSI_1_1 & .82 & & \\
\hline TSI_1_2 & .78 & & \\
\hline TSI_1_3 & .76 & & \\
\hline TSI_1_4 & .75 & & \\
\hline TSI_1_5 & .77 & & \\
\hline TSI_2_1 & & .83 & \\
\hline TSI_2_2 & & .81 & \\
\hline TSI_2_3 & & .82 & \\
\hline TSI_2_4 & & .84 & \\
\hline TSI_3_1 & & & .82 \\
\hline TSI_3_2 & & & .80 \\
\hline TSI_3_3 & & & .88 \\
\hline TSI_3_4 & & & .82 \\
\hline
\end{tabular}

Varimax Rotation, Variance explained $71 \%$

KMO: .84, Bartlett's Test of Sphericity chi-square $=1717.7, \mathrm{df}=78$, significance $=0.000$ 


\begin{tabular}{|c|c|c|c|c|c|}
\hline \multirow[b]{3}{*}{ TSE_1 } & \multicolumn{5}{|c|}{ Component } \\
\hline & 1 & 2 & 3 & 4 & 5 \\
\hline & .68 & & & & \\
\hline TSE_2 & .81 & & & & \\
\hline TSE_3 & .84 & & & & \\
\hline TSE_4 & .81 & & & & \\
\hline TSE_5 & .87 & & & & \\
\hline TSE_6 & .75 & & & & \\
\hline TEP_1 & & .72 & & & \\
\hline TEP_2 & & .72 & & & \\
\hline TEP_3 & & .79 & & & \\
\hline TEP_4 & & .68 & & & \\
\hline TEP_5 & & .77 & & & \\
\hline TEC_1 & & & .82 & & \\
\hline TEC_2 & & & .86 & & \\
\hline TEC_3 & & & .81 & & \\
\hline TEC_4 & & & .81 & & \\
\hline TEI_1 & & & & .76 & \\
\hline TEl_2 & & & & .88 & \\
\hline TEI_3 & & & & .83 & \\
\hline SP_1 & & & & & .98 \\
\hline SP_2 & & & & & .98 \\
\hline
\end{tabular}

Varimax Rotation, Variance explained 68\%

KMO.923, Bartlett's Test of Sphericity chi-square $=3378.8, \mathrm{df}=190$, significance $=0.000$ 


\begin{tabular}{|c|c|c|c|}
\hline \multicolumn{1}{|c|}{ Appendix Table 4: Composite Reliability, Communality and Redunancy } \\
\hline & $\begin{array}{c}\text { Composite } \\
\text { Reliability }\end{array}$ & Communality & Redundancy \\
\hline $\begin{array}{c}\text { Sales } \\
\text { Performance (SP) }\end{array}$ & 0.99 & 0.98 & 0.03 \\
\hline $\begin{array}{c}\text { Technology Self } \\
\text { Efficacy (TSE) }\end{array}$ & 0.91 & 0.63 & 0 \\
\hline $\begin{array}{c}\text { Technology } \\
\text { Competence } \\
\text { (TEC) }\end{array}$ & 0.92 & 0.74 & 0 \\
\hline $\begin{array}{c}\text { Technostress } \\
\text { Inhibitors (TSI) }\end{array}$ & 0.81 & 0.58 & 0.11 \\
\hline $\begin{array}{c}\text { Technostress } \\
\text { Creators (TSC) }\end{array}$ & 0.84 & 0.67 & 0.01 \\
\hline $\begin{array}{c}\text { Technology } \\
\text { Enabled } \\
\text { Innovation (TEI) }\end{array}$ & 0.94 & 0.83 & 0.17 \\
\hline $\begin{array}{c}\text { Technology } \\
\text { Enabled } \\
\text { Performance } \\
\text { (TEP) }\end{array}$ & 0.91 & 0.57 & 0 \\
\hline
\end{tabular}




\begin{tabular}{|l|l|l|}
\hline $\begin{array}{l}\text { Appendix Table 5: Analysis with Control Variables- Education, } \\
\text { Organizational tenure and Professional tenure }\end{array}$ \\
\hline Control Variable & SP & TEP \\
\hline Education & Not significant & $\begin{array}{l}\text { Positive } \\
\text { relationship } \\
\text {.013) }\end{array}$ \\
\hline Organizational Tenure & Not significant & Not significant \\
\hline Professional Tenure & $\begin{array}{l}\text { Positive relationship } \\
(p=.002)\end{array}$ & Not significant \\
\hline
\end{tabular}

